\title{
Potential Complementary Therapy for Adverse Drug Reactions to Sulfonamides: Chemoprotection Against Oxidative and Nitrosative Stress by TCM Constituents and Defined Mixtures
}

\author{
Lei Zhang ${ }^{1}$, Dao-Feng Chen², Xue Yan Xia ${ }^{1}$, Cindy Yip ${ }^{3}$, Michael J. Rieder ${ }^{3,4,5}$ and John R. Bend ${ }^{1,3,4}$
}

${ }^{1}$ Department of Pathology and Laboratory Medicine, Schulich Medicine \& Dentistry, Siebens-Drake Medical Research
Institute, Western University, London ON, Canada. ${ }^{2}$ Department of Pharmacognosy, School of Pharmacy, Fudan University,
Shanghai, China. ${ }^{3}$ Department of Physiology and Pharmacology, Schulich Medicine \& Dentistry, Western University.
Department of Paediatrics, Schulich Medicine \& Dentistry, Western University. ${ }^{5}$ Robarts Research Institute, Western
University.

Received, July 9, 2015; Revised, August11, 2015; Accepted, September 28, 2015; Published, September 30, 2015.

\begin{abstract}
PURPOSE: Our working hypothesis is that bioactive phytochemicals that are important constituents of Traditional Chinese Medicine and their defined mixtures have potential as complementary therapy for chemoprotection against adverse drug reactions whose toxicity is not related to the pharmacological action of the drug but where oxidative and nitrosative stress are causative factors. METHODS: In this investigation we measured cytotoxicity, lipid peroxidation, protein carbonylation and ROS/NOS-mediated changes in the disulfide proteome of Jurkat E6.1 cells resulting from exposure to sulfamethoxazole N-hydroxylamine with or without pretreatment with low $\mu \mathrm{M}$ concentrations of baicalein, crocetin, resveratrol and schisanhenol alone and in defined mixtures to compare the ability of these treatment regimens to protect against ROS/RNS toxicity to Jurkat E6.1 cells in culture. RESULTS: Each of the Traditional Chinese Medicine constituents and defined mixtures tested had significant chemoprotective effects against the toxicity of ROS/RNS formed by exposure of Jurkat E6.1 cells to reactive metabolites of sulfamethoxazole implicated as the causative factors in adverse drug reactions to sulfa drugs used for therapy. At equimolar concentrations, the defined mixtures tended to be more effective chemoprotectants overall than any of the single constituents against ROS/RNs toxicity in this context. CONCLUSIONS: At low $\mu \mathrm{M}$ concentrations, defined mixtures of TCM constituents that contain ingredients with varied structures and multiple mechanisms for chemoprotection have excellent potential for complementary therapy with sulfa drugs to attenuate adverse effects caused by oxidative/nitrosative stress. Typically, such mixtures will have a combination of immediate activity due to short in vivo half-lives of some ingredients cleared rapidly following metabolism by phase 2 conjugation enzymes; and some ingredients with more prolonged halflives and activity reliant on phase 1 oxidation enzymes for their metabolic clearance.
\end{abstract}

This article is open to POST-PUBLICATION REVIEW. Registered readers (see "For Readers") may comment by clicking on ABSTRACT on the issue's contents page.

\section{INTRODUCTION}

Adverse drug reactions (ADRs) are unintended consequences from drugs administered in recommended, standard doses for on label conditions and symptoms that cause increased morbidity, and even death (1). ADRs are a significant problem that accompanies administration of many drug classes, including the sulfonamide, sulfamethoxazole (SMX). The incidence of SMX-induced ADRs is reported to be $3-8 \%$ of treated patients but this rate increases dramatically to approximately $50 \%$ in oxidatively stressed patients infected with HIV (2).
It is commonly accepted that ADRs can be divided into two general classes, type A and type B (3). Type A reactions are dose-dependent and related to the pharmacological action of the drug, making them predictable. Type B reactions, on the other hand, are not predictable from the pharmacological action of the administered drug, do not show dosedependency and have delayed onset, reasons they are also called idiosyncratic ADRs.

Corresponding Author: Professor Jack Bend, Department of Pathology and Laboratory Medicine, Schulich Medicine \& Dentistry, Siebens-Drake Medical Research Institute, Western University, 1400 Western Road, London ON, Canada; Email: jack.bend@schulich.uwo.ca 
Type $\mathrm{B}$ reactions are less common, accounting for $20-25 \%$ of total ADRs (4). Idiosyncratic ADRs can be either immune-based, frequently termed allergic or drug hypersensitivity, or not have an immunological basis, in which case they are called pseudoallergic or non-allergic hypersensitivity reactions (5). Sulfonamides cause a variety of drug hypersensitivity-based idiosyncratic ADRs including fever, lymphadenopathy, skin rashes, hepatitis, nephritis, and blood dyscrasias, all of which are attributed to SMX reactive metabolites (6).

Consequently the metabolism of arylamines, including SMX, and the disposition of parent drug and its metabolites (Figure 1) become crucial in understanding the mechanisms responsible for these ADRs. The major phase 1 metabolic pathway for SMX is $\mathrm{N}$-acetylation to its $\mathrm{N}$-acetamide although minor conjugation to an $\mathrm{N}$-glucuronide also occurs (7). These are both detoxication reactions resulting in rapid elimination of SMX from the body. However, smaller and patient-variable amounts (up to $5 \%$ ) of SMX are oxidized to sulfamethoxazole Nhydroxylamine (SMX-NHOH), a metabolic activation reaction, primarily by the $\mathrm{P} 450$ monooxygenase isozyme, CYP2C9 (8) but also by myeloperoxidase (MPO) in activated neutrophils and lymphocytes (9); this latter reaction is likely more important in the etiology of the ADRs. SMX-NHOH undergoes auto-oxidation to the corresponding sulfamethoxazole N-nitroso metabolite (SMX-NO) believed responsible for idiosyncratic toxicity of SMX $(10,11)$, subsequent to formation of drugprotein antigens by covalent reaction with selected proteins $(6,12)$. Importantly, dendritic cells can convert SMX to SMX-NO intracellularly and generate co-stimulatory signals required to initiate a primary immune response (13).

In the absence of adequate detoxication (for example, by depletion of intracellular glutathione (GSH)), the immunogenic SMX-NO preferentially reacts with (ionized) reactive cysteine thiols of cellular proteins to form adducts, some of which are recognized as neo-antigens by the immune system. These haptens then provide an antigenic signal to $\mathrm{T}$ cells and elicit a $\mathrm{T}$ cell-mediated immune response which presents clinically as delayed-type hypersensitivity (Figure 1; 10,13). The SMX metabolites SMX-NHOH and SMX-NO are known to generate oxidative and nitrosative stress by forming reactive oxygen species (ROS) and reactive nitrogen species (RNS) (Figure 1) (10,14-17). This is consistent with the observations that lymphocyte exposure to SMX-NHOH results in the formation of ROS and intracellular GSH depletion $(14,15)$; SMX $(75 \mu \mathrm{M})$ increases ROS production and lipid peroxidation in BRL3A cells (16); and increasing SMX concentrations (up to $1.5 \mathrm{mM}$ ) result in concentration-dependent increases in ROS generation in normal human dermal fibroblasts (17). This is also supported by reports that ROS are formed during the oxidative metabolism of many xenobiotics in vivo (18). There remains controversy as to whether specific ADRs are due to covalent modification of proteins by electrophilic metabolites or due to ROS/RNS causing modifications of essential macromolecules, including proteins, lipids and nucleic acids $(19,20)$. In our opinion, either of these mechanisms can cause a drug-dependent hypersensitivity reaction but the intensity of the allergic response is intensified if both occur concomitantly, as with SMX (Figure 1).

In this context, we hypothesize that purified bioactive constituents of TCM that are potent chemoprotectant agents against ROS and NOS in vivo are candidates for complementary therapy for ROS- or RNS-mediated ADRs. We also postulate that defined mixtures of effective phytochemicals with diverse structures, different mechanisms of chemoprotectant action and different rates of metabolic elimination will be more effective than equimolar amounts of single TCM chemicals for complementary therapy in vivo.

The TCM phytochemicals evaluated here for chemoprotection against SMX-NHOH toxicity in vitro include Baicalein (BE), 5,6,7-trihydroxy-2phenylchromen-4-one (Figure 2A); Crocetin (Cro), (2E,4E,6E,8E,10E,12E,14E)-2,6,11,15-tetramethylhexadeca-2,4,6,8,10,12,14-heptaenedioic acid (Figure 2B); trans-Resveratrol (Res), 5-[(E)-2-(4hydroxyphenyl)ethenyl]benzene-1,3-diol (Figure 2C); and Schisanhenol (Sal), 5,6,7,8-tetrahydro2,3,10,11,12-pentamethoxy-6,7-dimethyldibenzo(a,c)cycloocten-1-ol (Figure 2D). Although all have antioxidant activity, the mechanisms for this activity vary somewhat for each chemical, in concert with their diverse structures (Figure 2).

BE, a flavonoid derived from the root of Scutellaria baicalensis is a constituent of multiple TCM prescriptions. It is used extensively as a remedy for treatment of respiratory tract infection, cancer (21) dysentery, jaundice, hepatitis and hypertension (22). 


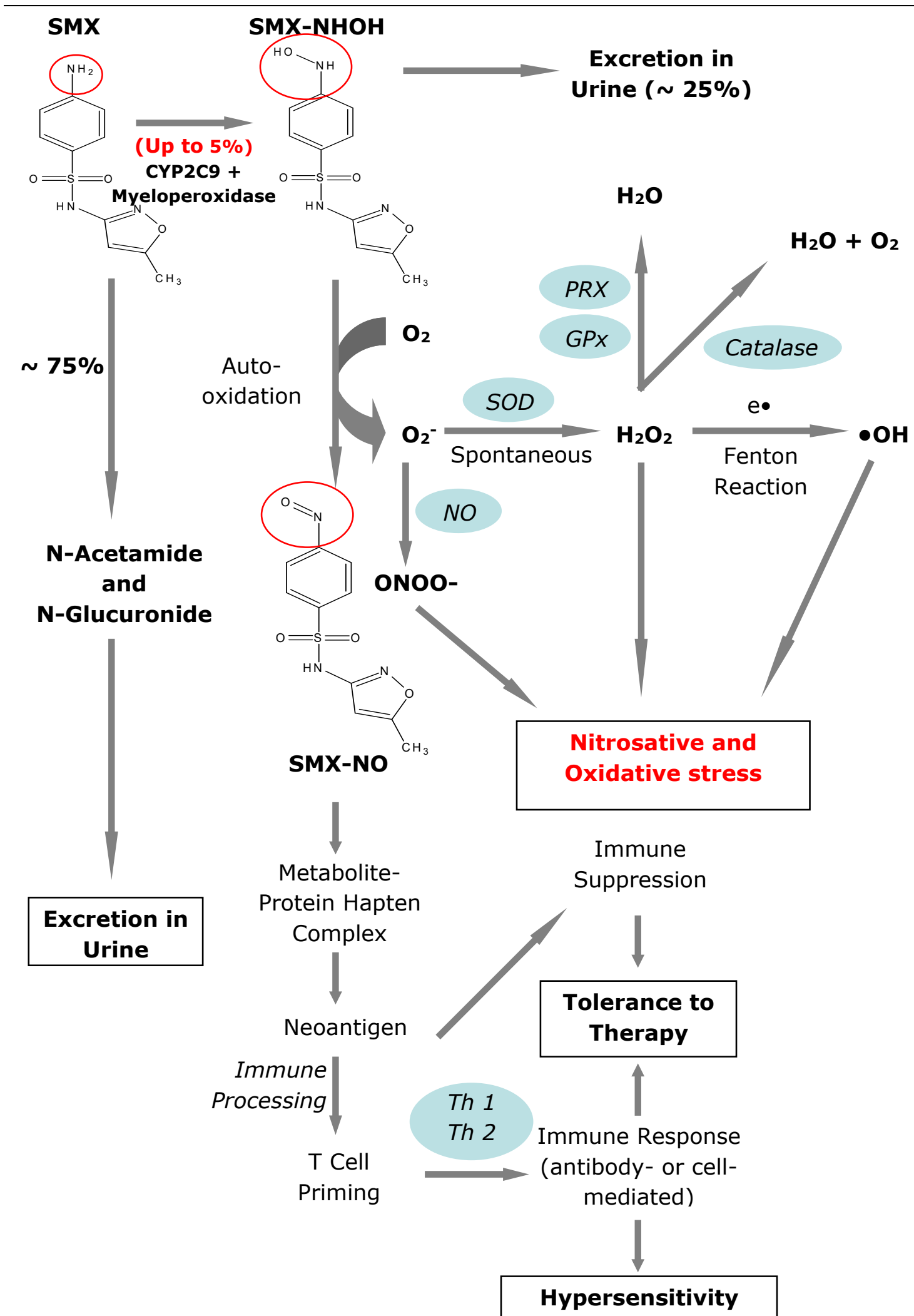

Figure 1. Proposed mechanism for formation of ROS, RNS and covalent SMX-NO-protein adducts from Nnitrososulfamethoxazole (SMX-NO), showing probable pathways to hypersensitivity-mediated ADRs 
Cro, one of the major constituents of saffron, is a carotenoid found in Crocus sativus (23) with reported anti-cancer and anti-atherosclerotic activity and effects that attenuate ethanol-induced memory impairment (24). Res is a trans-stilbene polyphenol often isolated from the root of white hellebore (25). It is a common constituent of TCM prescriptions investigated for chemoprotection against aging, inflammation (26), cancer, neurodegeneration (27), diabetes, viral infection and Alzheimer's (28). Sal is a dibenzocyclooctene lignin isolated from Schisandra rubriflora Rhed, an herb common in TCM prescriptions. Studies with this purified TCM have been uncommon because of its restricted availability. Sal effectively targets mitochondria, inhibiting lipid peroxidation (29), swelling, and reduction of membrane fluidity due to ROSmediated damage (30). It is also an effective scavenger of superoxide, R--, RO--, and ROO-radicals (31) and is reported to possess anti-tumor, anti-hepatitis (32), detoxicant, anti-HIV and attenuation of platelet-activating factor activity (33).

We elected to use Jurkat E6.1cells, a human leukemic $\mathrm{T}$ cell lymphoblast line, to evaluate the toxicity of the SMX metabolite, SMX-NHOH and the attenuation of this toxicity by low $\mu \mathrm{M}$ concentrations of the TCM constituents BE, Cro, Res or Sal and of two defined mixtures. The first (MIX 1) contains equimolar concentrations of BE, Cro, Res and Sal; the second mixture (MIX 2) contains equimolar concentrations of BE, Cro and Res. High numbers of $\mathrm{T}$ cells in blood and skin from patients with drug hypersensitivity reactions led researchers to conclude these cells function via an immune mechanism to regulate the development of immuneinduced ADRs (34), the reason we selected Jurkat E6.1 cells for this study.

The toxicological endpoints evaluated include cytotoxicity (lactate dehydrogenase (LDH) release); lipid peroxidation (analysis of lipid hydroperoxides formed) and protein carbonylation (analysis of protein aldehydes and ketones). In addition, we performed reductive-two dimensional SDSpolyacrylamide gel electrophoresis (R2D SDSPAGE) on lysate from control and treated Jurkat E6.1 cells to determine the number of protein mixed disulfides formed as a result of treatment with SMX$\mathrm{NHOH}$. This disulfide proteome is a measure of the reversible oxidation of redox-regulated proteins containing ionized cysteine protein thiol residues to homodimeric (P-SS-P) or heterodimeric (P-SS-P') protein-protein disulfides. Both ROS and RNS carry out this oxidation.

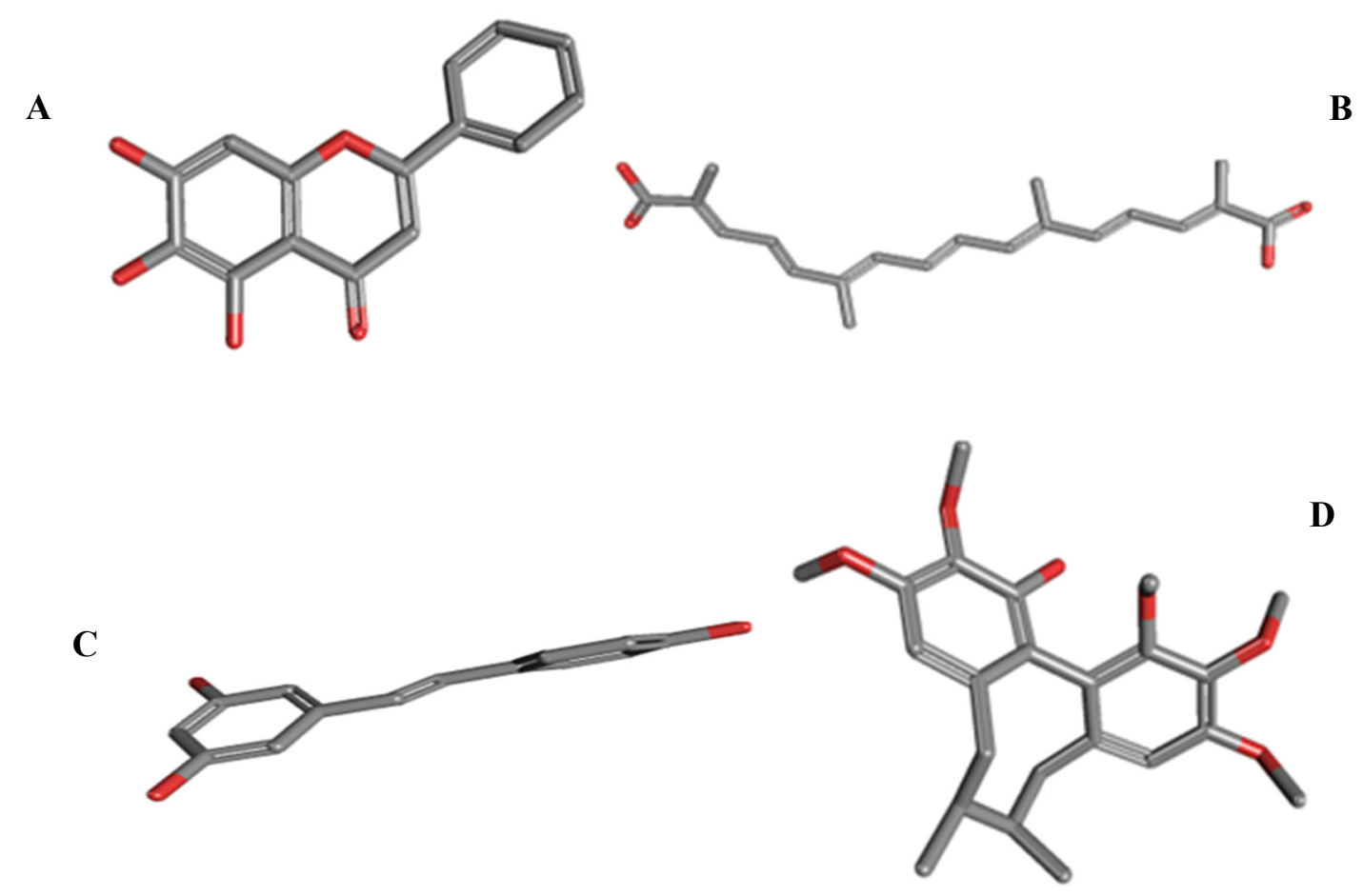

Figure 2: Three dimensional structures of Baicalein (BE, A); Crocetin (Cro, B); trans-Resveratrol (Res, C); and Schisanhenol (Sal; D). (From PubChem Public Chemical Database, http://pubchem.nbi.nlm.nih.gov) 
The purpose of this study is to determine whether or not low $\mu \mathrm{M}$ concentrations of 4 pure TCM phytochemicals with potent antioxidant activity alone or in defined mixtures have potential for complementary therapy with sulfonamides for chemoprotection against ADRs to these drugs.

\section{MATERIALS AND METHODS}

\section{Chemicals and Cell Culture Supplies}

The purest TCM constituents commercially available $(>95 \%)$ were used throughout; BE was purchased from Aldrich Chem. Co. (Milwaukee, WI); Cro from MP Biomedicals, LLC (Solon, Ohio); and Res from Sigma-Aldrich (Oakville, ON, Canada). Sal (>99\%) was isolated and purified from Schisandra rubriflora in the laboratory of Professor Chen $(33,35)$. SMX-NHOH $(>99 \%$ by HPLC) was synthesized according to Rieder et al (10). Dimethyl sulfoxide (DMSO), Hybri-Max ${ }^{\mathrm{TM}}$, Triton ${ }^{\circledR} \mathrm{X}-100$, L-lactic acid, iodonitrotetrazolium chloride (INT), phenazine methosulfate (PMS), dithiothreitol (DTT), iodoacetamide (IACD) and $\beta$-nicotinamide adenine dinucleotide (NAD) were purchased from SigmaAldrich (Oakville, ON, Canada). All other chemicals were purchased from BDH (Toronto, ON, Canada), EMD (San Diego, CA, USA) or Sigma-Aldrich and are the highest purity available commercially. Lipid Hydroperoxide (LPO) Assay kits (96 well) and Protein Carbonyl Assay kits were purchased from Cayman Chemical Company (Ann Arbor, MI).

BD Falcon ${ }^{\mathrm{TM}} 75$ or $150 \mathrm{~cm}^{2}$ tissue culture flasks; BD Falcon ${ }^{\mathrm{TM}} 5 \mathrm{ml}$ polypropylene round-bottom tubes; BD Falcon ${ }^{\mathrm{TM}} 5 \mathrm{ml}$ polystyrene round-bottom test tubes; Falcon ${ }^{\circledR}$ Blue $\operatorname{Max}^{\mathrm{TM}} 50 \mathrm{ml}$ polypropylene conical tubes; Falcon ${ }^{\circledR}$ Microtest $^{\mathrm{TM}}$ tissue culture flat-bottom 96-well plates; and Falcon ${ }^{\circledR}$ Multiwell $^{\mathrm{TM}}$ tissue culture flat-bottom 12 well plates used for culture of cells were purchased from BD Biosciences (Mississauga, ON).

\section{Cell Culture and Treatment}

The Jurkat E6.1 cells used throughout are a clone of the Jurkat-FHCRC line, derived from the original Jurkat cell line (36), and were obtained from the ATCC (\#TIB-152; http://www.atcc.org). RPMI medium was prepared and adjusted to $\mathrm{pH} 7.2$ by the addition of $2 \mathrm{~g}$ sodium bicarbonate/L. Cell concentrations were maintained between $1 \times 10^{5}$ and $1 \times 10^{6}$ cells $/ \mathrm{ml}$ by replacing medium every 2 to 3 days. Before experiments, cells at room temperature were transferred to $50 \mathrm{~mL}$ Falcon Blue tubes and centrifuged at $500 \times \mathrm{g}$ (Beckman GS-15R centrifuge) for $10 \mathrm{~min}$. The pellet was washed with $50 \mathrm{ml}$ phosphate buffered saline (PBS; $1.15 \times 10^{5}$ cells $/ \mathrm{ml}$; $5 \% \mathrm{Na}_{2} \mathrm{HPO} 4,0.2 \% \mathrm{KH}_{2} \mathrm{PO} 4,8.0 \% \mathrm{NaCl}, 0.2 \%$ $\mathrm{KCl}, \mathrm{pH} 7.4)$ and centrifuged again. For experiments, cells $\left(5 \times 10^{5}\right.$ cells $\left./ \mathrm{ml}\right)$ were resuspended in RPMI 1640 medium supplemented with Penicillin/Streptomycin $(\mathrm{P} / \mathrm{S})$, and routinely divided into multiple groups. They were seeded at $1 \times 10^{5}$ cells/well in triplicate for each group in flat-bottom 96-well plates. All test incubations were in a $5 \% \mathrm{CO}_{2}$ humidified environment at $37{ }^{\circ} \mathrm{C}$ and each experiment was repeated at least 3 times with a different cell culture each time.

The effects of the TCM constituents (BE, Cro, Res or Sal) alone and in combination; MIX 1 (equimolar mixture of BE, Cro, Res, Sal) and MIX 2 (equimolar mixture of BE, Cro and Res without Sal) were determined with Jurkat E6.1 cells in RPMI medium treated with solvent (no more than $0.2 \%$ DMSO; solvent control), various concentrations (0$400 \mu \mathrm{M})$ of BE, Cro, Res, Sal, MIX 1 or MIX 2 to evaluate their cytotoxicity; and at 5 and $20 \mu \mathrm{M}$ to evaluate chemoprotection against the toxicity of 400 $\mu \mathrm{M}$ of SMX or its reactive metabolite, SMX-NHOH. For chemoprotection experiments, cells were typically incubated with TCM constituents for 30 min before addition of SMX or SMX-NHOH. Cell protein concentrations were routinely determined with the Lowry assay (37).

\section{Cytotoxicity Determined by Release of Lactate Dehydrogenase (LDH) Activity}

Cytotoxicity was determined by measuring the release of LDH activity from cells into cell free supernatant using a colorimetric assay previously described (38). Briefly, Jurkat E6.1 cells were seeded at $2 \times 10^{5}$ cells $/ \mathrm{ml}$ for $6 \mathrm{~h}$ or $3 \times 10^{5}$ cells $/ \mathrm{ml}$ for $24 \mathrm{~h}$ experiments and treated with BE, Cro, Res, Sal, MIX 1 or MIX 2 (as described above) or $1 \%$ Triton X-100 (100\% LDH release), the positive control. Cell supernatant $(100 \mu \mathrm{l})$ was incubated with $100 \mu \mathrm{l}$ of LDH Reaction Mixture (LDH Assay Kit) and absorbance determined at $490 \mathrm{~nm}$ (Safire F129013, Tecan, Austria); absorbance values were collected using the XFluor 4 program. LDH leakage is expressed as a percentage of the high control after all values were adjusted using low control (solvent treatment only). 


\section{Lipid Peroxidation}

Lipid peroxide (LPO) formation was measured in Jurkat E6.1 cells with a Lipid Hydroperoxide Assay Kit that determines hydroperoxides directly (39), subsequent to treatment with $400 \mu \mathrm{M}$ SMX-NHOH for $2 \mathrm{~h}$ with or without pretreatment for $30 \mathrm{~min}$ as described above. Prior to treatment, Jurkat E6.1 cells were washed with PBS, resuspended in RPMI 1640 medium with $0.2 \% \mathrm{v} / \mathrm{v}$ BSA (assay medium), and adjusted to $5 \times 10^{5}$ cells $/ \mathrm{ml}$. Following incubation, cells were spun at $500 \times \mathrm{g}$ for $10 \mathrm{~min}$, resuspended in $1 \mathrm{ml}$ RPMI1640 medium and incubated for $18 \mathrm{~h}$ at 37 ${ }^{\circ} \mathrm{C}$.

Treated cells were then transferred into glass test tubes and sonicated in $500 \mu 1$ HPLC-grade water. An equal volume of Extract $\mathrm{R}$ saturated methanol solution was added to each tube, followed by $1 \mathrm{ml}$ cold deoxygenated chloroform and thorough mixing. Tubes were centrifuged at $500 \times \mathrm{g}$ for $5 \mathrm{~min}$ at $4^{\circ} \mathrm{C}$, the bottom chloroform layer collected and transferred into another glass test tube, which was stored at $-80^{\circ} \mathrm{C}$. An aliquot of the chloroform extract $(500 \mu \mathrm{l})$ was transferred to a glass tube, followed by $450 \mu \mathrm{l}$ chloroform-methanol (2:1). Freshly prepared chromogen $(50 \mu \mathrm{l})$, consisting of equal volumes of FTS Reagent 1 (4.5 mM ferrous sulphate in $0.2 \mathrm{M}$ $\mathrm{HCl})$ and $\mathrm{FTS}$ reagent $2(3 \%$ ammonium thiocyanate in aqueous methanol) was added to each assay and standard tube $(50 \mu \mathrm{M}$ 13-hydroperoxyoctadecadienoic acid (13-HpODE) in ethanol) and the tubes sealed tightly for $5 \mathrm{~min}$ at room temperature. Finally, $300 \mu 1$ from each tube was transferred to a 96-well glass plate and the absorbance read at $500 \mathrm{~nm}$ (Safire F129013, Tecan, Austria). Concentrations of lipid hydroperoxides were calculated by comparison to the 13-HpODE standard curve.

\section{Protein Carbonylation}

Irreversible oxidation of Lys, Arg, Pro or Thr residues in proteins to aldehydes and ketones is a major pathway for protein modification during oxidative stress, frequently resulting in loss of function $(40,41)$. Protein carbonyl content was analyzed in experiments designed to study the attenuation of SMX-NHOH-mediated protein carbonylation in Jurkat E6.1 cells by pretreatment with 5 or $20 \mu \mathrm{M} \mathrm{BE}$, Cro, Res or Sal, and MIX 1 or MIX 2 prior to exposure to $400 \mu \mathrm{M}$ SMX-NHOH (as described in more detail above).

We utilized the Caymen Chemical Protein Carbonyl Assay kit (10005020) which compares the concentration of 2,4-dinitrophenylhydrazones (yellow) in sample incubation mixtures formed by reaction of protein aldehydes and ketones with 2,4dinitrophenylhydrazine (DNPH) to identical control mixtures not reacted with DNPH. The amount of 2,4dinitrophenylhydrazones formed is quantified by absorbance at $360 \mathrm{~nm}$.

Cell preparation and treatment were as described for the assay of lipid hydroperoxides (above). After centrifugation, cells were resuspended and incubated for $18 \mathrm{~h}$ at $37^{\circ} \mathrm{C}$ and $2 \times 100 \mu \mathrm{l}$ aliquots transferred to $1.7 \mathrm{ml}$ microcentrifuge tubes, one as sample, one as control. DNPH reagent $(400 \mu \mathrm{l})$ was added to the sample tube, $2.5 \mathrm{M} \mathrm{HCl}(400 \mu \mathrm{l})$ to the control tube. Tubes were incubated in the dark for $1 \mathrm{~h}$ with vortex mixing every $15 \mathrm{~min}$. Trichloroacetic acid (TCA; 0.5 $\mathrm{ml} \mathrm{20 \% )} \mathrm{was} \mathrm{added} \mathrm{to} \mathrm{each} \mathrm{tube} \mathrm{to} \mathrm{precipitate}$ protein which was collected following centrifugation at $10,000 \times \mathrm{g}$ for $10 \mathrm{~min}$ at $4{ }^{\circ} \mathrm{C}$. The protein pellet was resuspended in $0.5 \mathrm{ml} \mathrm{10 \%} \mathrm{TCA} \mathrm{and} \mathrm{samples} \mathrm{re-}$ centrifuged at $10,000 \times \mathrm{g}$ for $10 \mathrm{~min}$ at $4{ }^{\circ} \mathrm{C}$. The supernatant was removed, the pellet resuspended in $0.5 \mathrm{ml}$ ethanol: ethyl acetate $(1: 1)$ and the samples centrifuged as before. The wash step with ethanol: ethyl acetate was repeated twice and the final protein pellet resuspended in $500 \mu \mathrm{l}$ guanidine hydrochloride solution by vortex mixing. Finally, $220 \mu 1$ of the supernatant from sample tubes and 200 $\mu 1$ from control tubes were transferred to a 96-well plate and the absorbance measured at $360 \mathrm{~nm}$ (Safire F129013, Tecan, Austria). The concentration of 2,4dinitrophenylhydrazones is determined after subtracting blank absorbance from sample absorbance and converted to concentration using an extinction coefficient of $22,000 \mathrm{M}^{-1}$ (42).

\section{Reductive Two-Dimensional SDS-Polyacryl- amide Gel Electrophoresis (R2D SDS-PAGE)}

Prior to treatment, Jurkat E6.1 cells were washed in PBS, resuspended in RPMI 1640 medium and the density adjusted to $8 \times 10^{5}$ cells $/ \mathrm{ml}$. Cells were seeded ( $2 \mathrm{ml} /$ well) in 6-well tissue culture plates to yield sufficient protein for analysis by R2D SDS-PAGE. Jurkat E6.1 cells were pretreated as described in detail above for $30 \mathrm{~min}$, followed by treatment with 0 or $400 \mu \mathrm{M}$ SMX-NHOH for $2 \mathrm{~h}$.

After the $2.5 \mathrm{~h}$ incubation, cells were collected in $2 \mathrm{ml} \mathrm{microcentrifuge} \mathrm{tubes} \mathrm{at} 500 \times \mathrm{g}$ for $5 \mathrm{~min}$. Cell pellets were resuspended in PBS, centrifuged again, resuspended in cold PBS and treated with 40 $\mathrm{mM}$ iodoacetamide (IACD) for $5 \mathrm{~min}$ to prevent thiol-disulfide exchange and post-lysis oxidation of 
free cysteine thiols (43). After IACD incubation, samples were recentrifuged and pellets resuspended in $50 \mu 1$ lysis buffer (one Roche Diagnostics protease inhibitor tablet added to $9 \mathrm{ml}$ lysis buffer, composed of $7.44 \mathrm{mg}$ EDTA, $0.12 \mathrm{~g}$ Tris, $0.76 \mathrm{~g} \mathrm{NaCl}, 0.159 \mathrm{~g}$ $\mathrm{NaH}_{2} \mathrm{PO} 4 \cdot 1 \mathrm{H}_{2} \mathrm{O}, 0.446 \mathrm{~g} \mathrm{Na} \mathrm{P}_{2} \mathrm{O}_{7} \cdot 10 \mathrm{H}_{2} \mathrm{O}, 0.042 \mathrm{~g}$ $\mathrm{NaF}$ ) dissolved in $100 \mu \mathrm{l}$ water and frozen in liquid nitrogen. The lysates were thawed at room temperature, centrifuged for $10 \mathrm{~min}$ at $14,000 \times \mathrm{g}$, and the mitochondrial supernatants collected. An aliquot was assayed for protein content by the Bradford procedure (44).

The gels for analysis in the first dimension (10\% acrylamide, $1.0 \mathrm{~mm}$ thickness) were prepared as previously described (43). Protein extract (less than $50 \mu \mathrm{l})$ containing equal volumes of SDS sample buffer and $85 \mu \mathrm{g}$ of supernatant protein were subjected to $10 \%$ non-reducing SDS-PAGE electrophoresis for $3 \mathrm{~h}$, using a constant current of 24 $\mathrm{mA} /$ gel with a Bio-Rad Protean II apparatus. Different gel lanes contained proteins for each individual treatment. After electrophoresis in the first-dimension, each gel lane was cut, placed in an individual glass dish and reduced with $10 \mathrm{ml}$ SDS sample buffer containing $100 \mathrm{mM}$ DTT. Following 3 washes with SDS running buffer (1 min/time), each gel lane was incubated in $10 \mathrm{ml}$ SDS sample buffer containing $100 \mathrm{mM}$ IACD. Each gel lane was placed horizontally on top of the second-dimension gel (10\% acrylamide, $1.5 \mathrm{~mm}$ thickness), fixed and sealed with $2 \%$ low melt agarose buffer. Electrophoresis was then performed in the second dimension for $14 \mathrm{~h}$ at a constant current of $10 \mathrm{~mA} / \mathrm{gel}$ (43).

After electrophoresis, gel slabs were placed in a Dodeca small stainer (Bio-Rad) for silver staining where the gel was first fixed using methanol: water, 1:1 for $30 \mathrm{~min}$ and washed twice $(5 \mathrm{~min} / \mathrm{each})$ with distilled water to remove methanol. After that, gels were incubated in sensitizer solution $(0.02 \%$ sodium thiosulfate) for $5 \mathrm{~min}$, washed twice with distilled water for $1 \mathrm{~min}$ each, immersed in cold $0.2 \%$ silver nitrate solution and incubated for $30 \mathrm{~min}$. Finally, gel slabs were rinsed with distilled water twice for $1 \mathrm{~min}$ and developed in an aqueous solution of $0.05 \%$ formaldehyde in 3\% sodium hydroxide. After the developer solution turned yellow and the desired intensity of staining (diagonal line and scattered spots on the gel) was achieved, gel slabs were placed in $5 \%$ acetic acid (45). Finally each gel slab was scanned prior to analysis of resolved proteins.

\section{STATISTICAL ANALYSIS}

Analysis of variance (ANOVA) followed by Bonferroni's multiple comparison post-test was used to test for statistical differences between groups. A probability of more than $95 \% \quad(\mathrm{P} \leq 0.05)$ was considered to be significant. The Student's $t$-test was used in some cases to compare the vehicle control and a treatment group; or to compare a TCM treatment with the effect of SMX-NHOH alone. GraphPad Prism Version 5.01 (GraphPad Software, Inc) was used for statistical analyses.

\section{RESULTS}

\section{Concentration-Dependent Cytotoxicity of TCM Constituents and Defined Mixtures in Jurkat E6.1 Cells}

We initially assessed the cytotoxicity of BE, Cro, Res, Sal, MIX 1 and MIX 2 in Jurkat E6.1 cells after $6 \mathrm{~h}$ incubation at concentrations ranging from 6.25 to $400 \mu \mathrm{M}$ (Table 1). At $25 \mu \mathrm{M}$ there was a small but significant release of $\mathrm{LDH}$ upon exposure to $\mathrm{BE}$ $(1.6 \%)$ or Cro $(1.9 \%)$ but no detectable cytotoxicity with the other regimens. At $50 \mu \mathrm{M}$, LDH release increased to approximately 3\% with these two compounds, still a low grade of toxicity. At the exaggerated concentration of $400 \mu \mathrm{M}$ (20-fold greater than the highest chemoprotectant concentration tested) Sal was the most cytotoxic of the TCM constituents, releasing $27 \%$ of LDH while Cro and MIX 1 (which contains Sal and Cro) each released about $50 \%$ of this amount. Importantly, at 100 and $400 \mu \mathrm{M}$, MIX 2 was significantly less toxic than all other TCM treatments, except for Sal at 100 $\mu \mathrm{M}$ and $\mathrm{BE}$ at $400 \mu \mathrm{M}$. In both these cases the mean for LDH release was lower for MIX 1 than for Sal or $\mathrm{BE}$ but the difference was not significant. We also evaluated cytotoxicity after $24 \mathrm{~h}$ of exposure to each of these regimens (data not shown). Not surprisingly more LDH was released after $24 \mathrm{~h}$ than $6 \mathrm{~h}$ of exposure (27.4 \pm 0.8 vs $6.9 \pm 0.3 \%$ for BE; $11.4 \pm 0.1$ vs $3.3 \pm 9.1 \%$ for MIX 1. In addition, Sal was almost twice as cytotoxic after $24 \mathrm{~h}$ than MIX 1, which contained Sal ( $35.6 \pm 0.03$ vs $19.5 \pm 0.2 \%)$. These latter observations support our hypothesis that mixtures of TCM agents will be less toxic than single chemicals in complementary therapy. 


\begin{tabular}{|c|c|c|c|c|c|}
\hline TCM & $6.25 \mu \mathrm{M}$ & $25 \mu \mathrm{M}$ & $50 \mu \mathrm{M}$ & $100 \mu \mathrm{M}$ & $400 \mu \mathrm{M}$ \\
\hline Baicalein & $1.1 \pm 0.05^{1}$ & $1.6 \pm 0.1^{1}$ & $3.1 \pm 0.06^{1,2}$ & $3.9 \pm 0.1^{1,2}$ & $6.9 \pm 0.3^{2}$ \\
\hline Crocetin & $1.2 \pm 0.03^{1}$ & $1.9 \pm 0.09^{1,2}$ & $3.0 \pm 0.1^{1,2}$ & $4.6 \pm 0.1^{1,2}$ & $13.8 \pm 0.2^{1,2}$ \\
\hline Resveratrol & 0 & $0.7 \pm 0.08$ & $1.1 \pm 0.05^{1,2}$ & $3.4 \pm 0.1^{1,2}$ & $8.9 \pm 0.05^{1,2}$ \\
\hline Schisanhenol & $\mathbf{0}$ & 0 & $0.2 \pm 0.1$ & $2.8 \pm 0.2^{2}$ & $26.8 \pm 0.3^{1,2}$ \\
\hline MIX $1^{3}$ & $0.03 \pm 0.007$ & $0.6 \pm 0.1$ & $2.3 \pm 0.1^{1}$ & $3.6 \pm 0.1^{1,2}$ & $12.8 \pm 0.2^{1,2}$ \\
\hline MIX $2^{4}$ & 0 & 0 & $0.04 \pm 0.002$ & $0.4 \pm 0.03$ & $3.3 \pm 0.1^{2}$ \\
\hline \multicolumn{6}{|c|}{$\begin{array}{l}{ }^{1} \mathrm{P} \leq 0.05 \text {, within concentration comparison to MIX } 2 \text {, the } \\
(400 \mu \mathrm{M}) \text { tested } \\
{ }^{2} \mathrm{P} \leq 0.05 \text {, individual treatment vs } 0 \mu \mathrm{M} \text { solvent control } \\
{ }^{3} \mathrm{MIX} 1 \text { is equimolar BE, Cro, Res and Sal } \\
{ }^{4} \mathrm{MIX} 2 \text { is equimolar BE, Cro and Res }\end{array}$} \\
\hline
\end{tabular}

\section{Attenuation of SMX-HA-Mediated Cytotoxicity in Jurkat E6.1 Cells by Pretreatment with TCM Constituents Alone and in Defined Mixtures}

The cytotoxicity of SMX-NHOH $(400 \mu \mathrm{M}$ treatment for $2 \mathrm{~h}$ ) was assessed by release of LDH from Jurkat E6.1 cells in culture. Typically $28-32 \%$ of total intracellular LDH was released when corrected for release by solvent controls (Figure 3; $29.0 \pm 4.7 \%$, mean $\pm \mathrm{SEM}, \mathrm{N}=3$ ), a significant cytotoxic response ( $\mathrm{P} \leq 0.05$ vs solvent controls). The observed cytotoxicity is due both to the SMX-NHOH added to the incubation mixture and to SMX-NO formed by auto-oxidation during aerobic incubation (Figure 1). Both of these metabolites are electrophiles, accounting for the covalent binding of SMX$\mathrm{NHOH} / \mathrm{SMX}-\mathrm{NO}$ to cellular proteins $(6,12,15,17)$. They also contribute to cytotoxicity by depletion of intracellular GSH, with increased lipid peroxidation and irreversible oxidation of proteins occurring as secondary effects.

To test for chemoprotection of the TCM regimens against SMX-NHOH cytotoxicity we pretreated Jurkat E6.1 cells with 1 or $5 \mu \mathrm{M}$ of each TCM (or $0.2 \%$ DMSO as solvent control) for $30 \mathrm{~min}$ prior to exposure to the SMX metabolite. Each of these treatments partially decreased the release of $\mathrm{LDH}$ in a concentration-dependent manner. At 1 $\mu \mathrm{M}$, Cro reduced $\mathrm{LDH}$ release by approximately $65 \%$ (vs solvent controls), a notable chemoprotective effect. In comparison, MIX 1 decreased SMX$\mathrm{NHOH}-$ mediated release of LDH by $55 \%$ at $1 \mu \mathrm{M}$ and $93 \%$ at $5 \mu \mathrm{M}$ (Table 2). In other words, pretreatment with $5 \mu \mathrm{M}$ MIX 1 almost completely attenuated the cytotoxicity of $400 \mu \mathrm{M}$ SMX-NHOH or SMX-HA (SMX-hydroxylamine) to E6.1 cells.

With the exception of BE, each of the TCM ingredients and the 2 defined mixtures evaluated significantly decreased the cytotoxicity of SMX-HA in Jurkat E6.1 cells at $5 \mu \mathrm{M}$ (Figure 3, Table 1). The rank order (best to worst) of efficacy at $1 \mu \mathrm{M}$ for attenuation of SMX-NHOH toxicity is Cro, MIX 1, MIX 2, Res, Sal and BE; and at $5 \mu \mathrm{M}$ is MIX 1, MIX 2, Cro, Sal, Res and BE. BE offers significantly less chemoprotection against SMX-NHOH cytotoxicity than any of the other treatments $(\mathrm{P} \leq 0.05$; Table 2$)$, and although differences amongst the more efficacious treatments are not significant, MIX 1 and MIX 2 do comparatively well with over $90 \%$ chemoprotection at $5 \mu \mathrm{M}$ in each case.

\section{Attenuation of SMX-NHOH-Mediated Lipid Peroxidation in Jurkat E6.1 Cells by Pre- treatment with TCM Constituents Alone and in Defined Mixtures}

Lipids are important structural components of cell membranes and serve as primary targets for oxidative modification by ROS radicals which preferentially react with unsaturated fatty acids and esters in membranes (46). In this context, lipid peroxidation changes the structure and function of membrane lipids and results in the formation of highly reactive and unstable hydroperoxides. As SMX-NHOH is known to cause oxidative stress $(13,14$; Figure 1), its effects on lipid peroxidation were evaluated under the same treatment conditions (exposure to $400 \mu \mathrm{M}$ SMX-NHOH for $2 \mathrm{~h}$ ) used to determine its cytotoxicity (Figure 3; Table 1). Upon incubation with Jurkat E6.1 cells, SMX-NHOH increased lipid peroxidation a bit more than 2-fold (from $7.9 \pm 0.5$ to $16.8 \pm 1.2 \mu \mathrm{mol}$ lipid hydroperoxides formed per incubation mixture) compared to solvent controls (mean $\pm \mathrm{SEM}, \mathrm{N}=3$; Figure 4). 


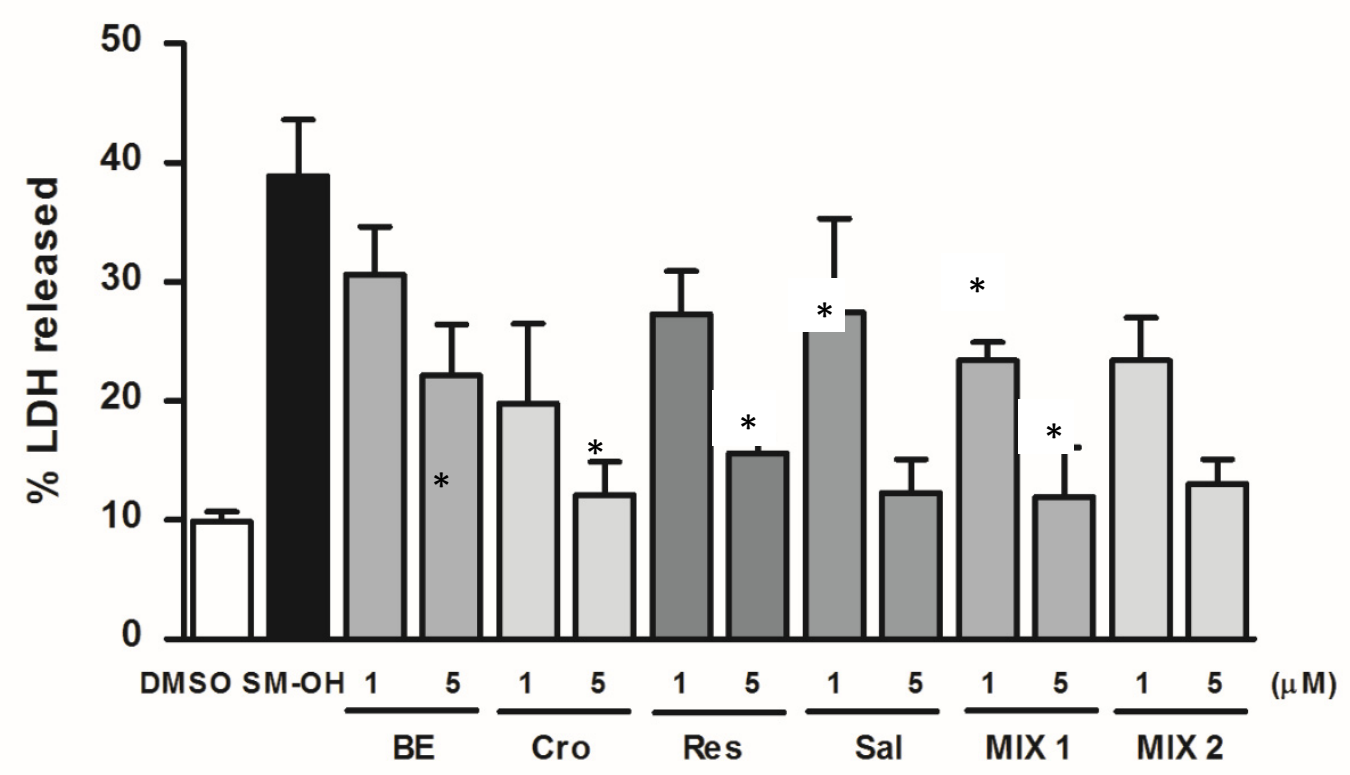

Figure 3: Attenuation of LDH release from Jurkat E6.1 cells treated with SMX-NHOH (400 $\mu$ M for 2 h) by pre-treatment with 1 or $5 \mu \mathrm{M}$ BE, Cro, Res, Sal, MIX 1 or MIX 2 for 30 min. Data are expressed as mean \pm SEM, N=3 different cell cultures. MIX 1 is equimolar BE, Cro, Res and Sal; MIX 2 is equimolar BE, Cro and Res. *Significantly lower than SMXNHOH $(400 \mu \mathrm{M})$ cytotoxicity $(\mathrm{P}<0.05$; Student's $t$-test $(\mathrm{P}<0.05)$ demonstrating attenuation of cytotoxicity by all treatments except BE at $5 \mu \mathrm{M}$ and only MIX 1 at $1 \mu \mathrm{M}$.

Table 2: Attenuation of the release of intracellular LDH from Jurkat E6.1 cells by pre-treatment with TCM constituents alone or in defined mixtures for $30 \mathrm{~min}$ prior to treatment with $400 \mu \mathrm{M}$ SMXNHOH for $2 \mathrm{~h}$. Data are expressed as mean \pm SEM, N=3 different cell cultures.

\begin{tabular}{lcc}
\hline TCM Treatment Regimen & \multicolumn{3}{c}{ \% Decrease of LDH Release } \\
\hline Concentration & $\mathbf{1} \boldsymbol{\mu M}$ & $\mathbf{5} \boldsymbol{\mu M}$ \\
MIX 1 & $\mathbf{5 4 . 9} \pm \mathbf{1 . 4}$ & $\mathbf{9 3 . 4} \pm \mathbf{0 . 8}$ \\
MIX 2 & $\mathbf{5 2 . 9} \pm \mathbf{0 . 7}$ & $\mathbf{9 3 . 1} \pm \mathbf{0 . 4}$ \\
Crocetin & $\mathbf{6 4 . 9} \pm \mathbf{1 . 9}$ & $\mathbf{8 5 . 4} \pm \mathbf{0 . 7}$ \\
Resveratrol & $\mathbf{3 9 . 9} \pm \mathbf{0 . 9}$ & $\mathbf{7 9 . 8} \pm \mathbf{0 . 7}$ \\
Schisanhenol & $\mathbf{3 9 . 5} \pm \mathbf{2 . 6}$ & $\mathbf{8 2 . 4} \pm \mathbf{1 . 3}$ \\
Baicalein & $\mathbf{3 0 . 9} \pm \mathbf{1 . 2}^{\mathbf{1}}$ & $\mathbf{5 7 . 5} \pm \mathbf{1 . 9}$ \\
\hline
\end{tabular}

${ }^{1}$ Differences between \% LDH released determined by Student's $t$-test within each TCM concentration range (P $\leq 0.05$, vs MIX 1). TCM regimens are listed in decreasing order of efficacy at $1 \mu \mathrm{M}$. MIX 1 is equimolar BE, Cro, Res and Sal; MIX 2 is equimolar BE, Cro and Res.

To evaluate the ability of the $6 \mathrm{TCM}$ treatments to attenuate lipid peroxidation caused by $400 \mu \mathrm{M}$ SMX-NHOH, Jurkat E6.1 cells were pre-treated with 5 and $20 \mu \mathrm{M}$ BE, Cro, Res, Sal, MIX 1 or MIX 2 for $30 \mathrm{~min}$. These concentrations of TCM were not cytotoxic because they did not increase LDH release (Figure 3). At 5 or $20 \mu \mathrm{M}$ each of the treatments with single TCM chemicals and defined mixtures significantly decreased lipid peroxidation $(\mathrm{P} \leq 0.05)$ caused by treatment with SMX-NHOH (Table 3). The rank order (best to worst) of efficacy at $5 \mu \mathrm{M}$ for attenuation of this lipid peroxidation is Cro, Res, Sal, MIX 1, BE, and MIX 2; and at $20 \mu \mathrm{M}$ is MIX 1, MIX 2, Res, Sal, Cro and BE. Chemoprotection against lipid peroxidation was significantly greater at $5 \mu \mathrm{M}$ for Cro and Res than for $\mathrm{BE}(\mathrm{P} \leq 0.05$; Table 2$)$. All TCM treatments were effective at $20 \mu \mathrm{M}$ and attenuated more than $80 \%$ of SMX-NHOHassociated lipid peroxidation. At $20 \mu \mathrm{M}$, MIX 1 and MIX 2 each inhibited lipid peroxidation by more than $93 \%$. 


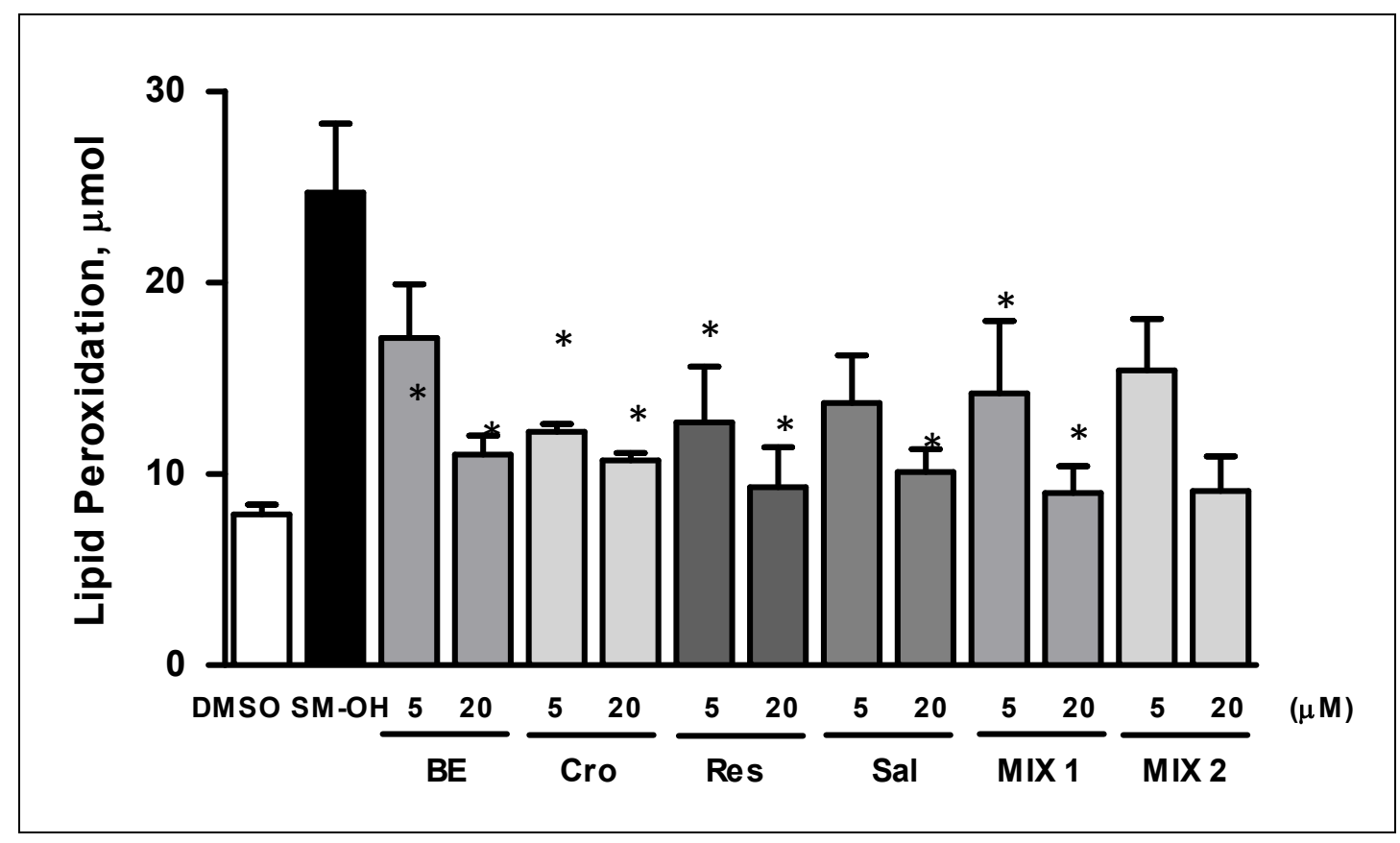

Figure 4: Attenuation of lipid peroxidation in Jurkat E6.1 cells treated with SMX-NHOH (400 $\mu \mathrm{M}$ for 2 h) by pre-treatment with 5 or $20 \mu \mathrm{M}$ BE, Cro, Res, Sal, MIX 1 or MIX 2 for $30 \mathrm{~min}$. Data are expressed as mean $\pm \mathrm{SEM}, \mathrm{N}=3$ different cell cultures. Lipid peroxidation following each treatment was compared to that formed in SMX-NHOH-treated cells. MIX 1 is equimolar BE, Cro, Res and Sal; MIX 2 is equimolar BE, Cro and Res. *Significantly lower than SMX-NHOH (400 $\mu$ M)mediated lipid peroxidation ( $\mathrm{P} \leq 0.05$; Student's $t$-test) demonstrating significant attenuation of ROS toxicity by all TCM treatments at $20 \mu \mathrm{M}$ and at $5 \mu \overline{\mathrm{M}}$.

\section{Attenuation of SMX-NHOH-Mediated Protein Carbonylation in Jurkat E6.1 Cells by Pretreatment with TCM Constituents Alone and in Defined Mixtures}

Irreversible protein oxidation is an important toxication reaction in ROS and RNS pathology $(18,39.40)$, the reason we determined the effect of SMX-NHOH exposure ( $400 \mu \mathrm{M}$ for $2 \mathrm{~h})$ on protein carbonylation. To our knowledge this is the first time this toxicological endpoint has been evaluated for $\mathrm{SMX}-\mathrm{NHOH} / \mathrm{SMX}-\mathrm{NO}$ in vitro. Incubation of Jurkat E6.1 cells with SMX-NHOH increased protein carbonyl formation by more than 2 -fold $(245 \pm 28 \%$, mean $\pm \mathrm{SEM}, \mathrm{N}=3)$ for treated vs $100 \%$ for solvent controls (Figure 7). Once again this toxicological effect is almost certainly due to the combined oxidative stressor and electrophilic metabolite characteristics of SMX-NHOH and its auto-oxidation product, SMX-NO because these two electrophiles will deplete GSH before preferentially binding to protein, enhancing ROS/RNS initiated protein carbonylation.

To evaluate chemoprevention against SMX$\mathrm{NHOH}-$ mediated protein carbonylation, Jurkat E6.1 cells were treated with 5 or $20 \mu \mathrm{M}$ of pure TCM constituents or the 2 defined mixtures for $30 \mathrm{~min}$ before SMX-NHOH exposure ( $400 \mu \mathrm{M}$ for $2 \mathrm{~h}$ ). The concentration of the phytochemicals used is the same as for the lipid peroxidation experiments (Figure 4; Table 3). Of the TCMs tested only Res significantly increased protein carbonylation (vs solvent controls), an effect that occurred at $5 \mu \mathrm{M}$ but not $20 \mu \mathrm{M}$ (data not shown). An apparent but insignificant increase is observed with $5 \mu \mathrm{M}$ Sal (Figure 7).

Sal $(5 \mu \mathrm{M}$ and $20 \mu \mathrm{M})$ decreased protein carbonylation due to SMX-NHOH by $45.8 \pm 5.3 \%$ and $71.3 \pm 1.0 \%$, respectively (Figure 7; Table 4). On the other hand, MIX 1 seemed slightly more effective, inhibiting protein carbonylation by $74.5 \pm$ $3.8 \%$ at $5 \mu \mathrm{M}$ and $81.8 \pm 3.9 \%$ at $20 \mu \mathrm{M}$ (Figure 8 ; Table 2).

All TCM treatments were effective at $5 \mu \mathrm{M}$ because they inhibited SMX-NHOH-mediated protein carbonylation by more than $45 \%$ (Table 3 ). Protein carbonylation was inhibited more than 59\% by each TCM treatment regimen at $20 \mu \mathrm{M}$. There seems an experimental anomaly here however, because MIX 2 inhibited lipid peroxidation by 
almost $70 \%$ at $5 \mu \mathrm{M}$ but only $59 \%$ at $20 \mu \mathrm{M}$. The rank order (best to worst) of efficacy at $5 \mu \mathrm{M}$ for chemoprevention of SMX-NHOH-mediated protein carbonylation is MIX 1, MIX 2, Cro, Sal and BE. Res showed negligible protection (6.1\% inhibition). The rank order at $20 \mu \mathrm{M}$ is MIX 1, BE, Cro, Sal, Res and MIX 2. At $5 \mu \mathrm{M}$, MIX 1 was significantly more effective than Sal, BE and Res (Table 4). It was 20\% more effective than the other single constituent, Cro, demonstrating the superiority of MIX 1 vs equimolar concentrations of all single TCM phytochemicals tested for suppression of protein carbonylation (Table 3).

\section{Attenuation of SMX-NHOH-Mediated Oxidative Changes in the Disulfide Proteome in Jurkat E6.1 Cells by Pretreatment with TCM Constituents Alone and in Defined Mixtures}

The disulfide proteome is comprised of a small subsection of proteins, numbering in the hundreds, that are redox-regulated by oxidation of a reactive cysteine thiol moiety $(41,42,43,47-49)$. Reactive cysteine thiols are ionized at physiological $\mathrm{pH}$ making them more nucleophilic and more easily oxidized by ROS and RNS. After initial oxidation with $\mathrm{H}_{2} \mathrm{O}_{2}$ protein reactive cysteine thiols are converted to their sulfenic acid (P-SOH) derivatives which react rapidly with GSH to yield Sglutathionylated products, called glutathione-protein mixed disulfides (P-SS-G). Protein reactive cysteine thiols also react with $\mathrm{NO}$, possibly via NO-GSH to form S-glutathionylated proteins $(41,48,49)$. SGlutathionylated proteins and protein-protein disulfides are readily converted back to thiols as the cell becomes more reduced, the reason $\mathrm{S}$ glutathionylation is cytoprotective for exposure to moderate concentrations of ROS and RNS
$(41,43,47,48,49)$. Following depletion of $\mathrm{GSH}$, proteins are oxidized by ROS and RNS to proteinprotein disulfides which can be homodimeric (P-SS$\mathrm{P})$ or heterodimeric (P-SS-P'). These disulfides are the products detected by R2D SDS-PAGE, because prior to PAGE in the second dimension, they are reduced to monomeric protein thiols by $100 \mathrm{mM}$ DTT. Proteins with intramolecular double bonds are also detected by this procedure because, upon reduction, they show an apparent increase in molecular weight (running to the left of the line of identity in the redox 2D gel) as opposed to P-SS-P and P-SS-P' which show a dramatic decrease in mol wt and run to the right of the line of identity (43). In the presence of excess ROS and RNS almost all proteins with reactive cysteine thiols become irreversibly oxidized to their sulfinic acid $\left(\mathrm{P}-\mathrm{SO}_{2} \mathrm{H}\right)$ and sulfonic acid $\left(\mathrm{P}-\mathrm{SO}_{3} \mathrm{H}\right)$ forms, a toxic response. $\mathrm{P}_{-} \mathrm{SO}_{2} \mathrm{H}$ and $\mathrm{P}-\mathrm{SO}_{3} \mathrm{H}$ are not detected by R2D SDS PAGE because they are not reduced by $100 \mathrm{mM}$ DTT.

Spot 1 on the various gels is peroxiredoxin 2 (prx 2 ), a cytosolic protein we have identified as a major disulfide in HEK 293 cells (human origin) by mass spectrometry/peptide mass fingerprinting (MS/PMF) after separation by R2D SDS-PAGE (50). Prx 2 is clearly visible after R2D SDS-PAGE of mitochondrial supernatant from untreated (data not shown) or DMSO-treated Jurkat E6.1 cells (Figure 6A; solvent control). In addition to prx 2, four other spots formed by reduction of P-SS-P/P' are clearly visible (labelled 2-5) in these DMSO-treated cells. There are also 2 significant spots (6 and 7) that appear to the left of the line of identity and are proteins resulting from reduction of their intramolecular disulfide bond(s) (43).

Table 3: Attenuation of lipid peroxidation in Jurkat E6.1 cells by pre-treatment with TCM constituents alone or in defined mixtures for 30 min prior to treatment with $400 \mu \mathrm{M}$ SMX-NHOH for $2 \mathrm{~h}$. Data are expressed as mean \pm SEM, $\mathrm{N}=3$ separate cell preparations. MIX 1 is equimolar BE, Cro, Res and Sal; MIX 2 is equimolar BE, Cro and Res.

\begin{tabular}{lcc}
\hline \multicolumn{1}{c}{ TCM Treatment Regimen } & \% Decrease of Lipid Hydroperoxide Formation \\
\hline Concentration & $\mathbf{5} \boldsymbol{\mu M}$ & $\mathbf{2 0} \boldsymbol{\mu M}$ \\
Resveratrol & $\mathbf{7 1 . 8} \pm \mathbf{3 . 7 ^ { 1 }}$ & $\mathbf{9 2 . 5} \pm \mathbf{3 . 1}$ \\
Crocetin & $\mathbf{7 2 . 1} \pm \mathbf{1 . 7}$ & $\mathbf{8 3 . 8} \pm \mathbf{1 . 6}$ \\
Schisanhenol & $\mathbf{6 5 . 8} \pm \mathbf{4 . 7}$ & $\mathbf{9 1 . 1} \pm \mathbf{3 . 4}$ \\
MIX 1 & $\mathbf{4 7 . 0} \pm \mathbf{1 . 0}$ & $\mathbf{9 5 . 6} \pm \mathbf{5 . 1}$ \\
Baicalein & $\mathbf{4 4 . 2} \pm \mathbf{3 . 6}$ & $\mathbf{8 1 . 5} \pm \mathbf{2 . 1}$ \\
MIX 2 & $\mathbf{4 1 . 6} \pm \mathbf{1 . 1}$ & $\mathbf{9 3 . 4} \pm \mathbf{5 . 9}$ \\
\hline
\end{tabular}

${ }^{1}$ Differences between lipid peroxide formed by exposure to SMX-NHOH determined by Student's $t$-test within each concentration range $(\mathrm{P} \leq 0.05$ vs MIX 1). TCM regimens are listed in decreasing order of efficacy at $5 \mu \mathrm{M}$. 


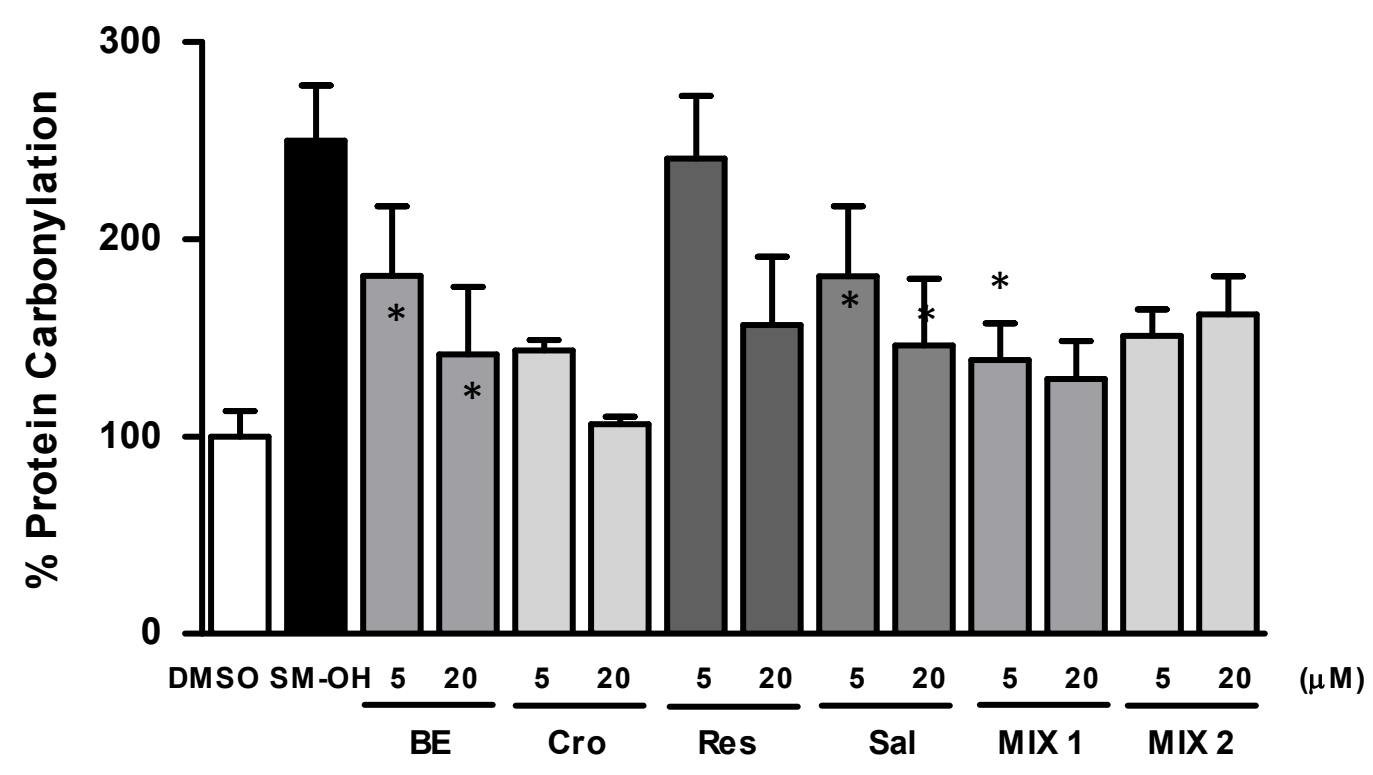

Figure 5. Attenuation of protein carbonylation in Jurkat E6.1 cells treated with SMX-NHOH ( $400 \mu \mathrm{M}$ for $2 \mathrm{~h})$ by pretreatment with 5 or $20 \mu \mathrm{M}$ BE, Cro, Res, Sal, MIX 1 or MIX 2 for $30 \mathrm{~min}$. Data are expressed as mean \pm standard error, N= 3 different cell cultures. MIX 1 is equimolar BE, Cro, Res and Sal; MIX 2 is equimolar BE, Cro and Res.*Significantly lower than SMX-NHOH $(400 \mu \mathrm{M})$-mediated protein carbonylation ( $\mathrm{P}<0.05$; Student's $t$-test $)$ demonstrating significant attenuation of irreversible protein oxidation at carbonyl by Cro and MIX 1 at 5 and $20 \mu \mathrm{M}$ and MIX 2 only at $5 \mu \mathrm{M}$.

Table 4. Attenuation of SMX-NHOH initiated protein carbonylation in Jurkat E6.1 cells by pre-treatment with 5 or 20 $\mu \mathrm{M}$ BE, Cro, Res, Sal, MIX 1 or MIX 2 for 30 min. Data are expressed as mean $\pm \mathrm{SEM}, \mathrm{N}=3$ different cell cultures. The decrease in protein carbonylation for each of the other treatments was compared to chemoprotection of MIX 1 (Student's $t$-test; ${ }^{1} \mathrm{P} \leq 0.05$ vs MIX 1$)$.

\begin{tabular}{lcc}
$t$-test; ${ }^{1} \mathrm{P} \leq 0.05$ vs MIX 1). & \multicolumn{3}{c}{$\begin{array}{l}\text { Effect of pre-treatment with TCM on protein carbonylation due to treatment with SMX- } \\
\text { NHOH }(\mathbf{4 0 0} \boldsymbol{\mu M} ; \mathbf{2 h})(\% \text { decrease; mean } \pm \text { SEM, N=3) }\end{array}$} \\
\hline Compound & $\mathbf{5 \mu M}$ & $\mathbf{2 0} \boldsymbol{\mu M}$ \\
\hline MIX 1 & $\mathbf{7 4 . 5} \pm 3.8$ & $\mathbf{8 1 . 8} \pm 3.9$ \\
MIX 2 & $\mathbf{6 6 . 8} \pm 5.2$ & $\mathbf{5 9 . 2} \pm 6.5$ \\
Crocetin & $\mathbf{5 5 . 0} \pm 4.3$ & $\mathbf{7 1 . 8} \pm \mathbf{1 . 9}$ \\
Schisanhenol & $\mathbf{4 5 . 8} \pm 5.3^{1}$ & $\mathbf{7 1 . 3} \pm 1.9$ \\
Baicalein & $\mathbf{4 5 . 7} \pm \mathbf{5 . 5}^{1}$ & $\mathbf{7 3 . 6} \pm \mathbf{1 . 8}$ \\
Resveratrol & $\mathbf{6 . 1} \pm \mathbf{1 . 4}^{1}$ & $\mathbf{6 2 . 6} \pm \mathbf{8 . 6}$ \\
\hline
\end{tabular}

Upon treatment with $400 \mu \mathrm{M}$ SMX-NHOH there are significant oxidative changes to the disulfide proteome of Jurkat E6.1 cells. The most dramatic is the disappearance of prx 2, which occurs in untreated cells as a disulfide-linked dimeric protein, prx2-SSprx 2 which is reduced to prx2-SH by DTT. Prx2 is a 2-Cys peroxiredoxin involved in the reduction of low, endogenous concentrations of $\mathrm{H}_{2} \mathrm{O}_{2}(51-54)$. Prx2 is oxidized to prx2- $\mathrm{SO}_{2} \mathrm{H}$ by $\mathrm{SMX}-\mathrm{NHOH}$ (Figure 6B) and other oxidative stressors including $t$ butyl hydroperoxide (50). SMX-NHOH-treated
Jurkat E6.1 cells also contained several novel spots, labelled by the letters "a" through "l" in Figure 6B and Table 5.

Jurkat E6.1 cells also contained several novel spots, labelled by the letters "a" through "l" in Figure 6B and Table 5. Most of these SMX-NHOH-specific protein spots from DDT reduction of intermolecular protein disulfides (i.e. spots were below and to the right of the line of identity). These novel disulfides were formed by oxidation of proteins at reactive cysteine thiols by SMX-NHOH. 

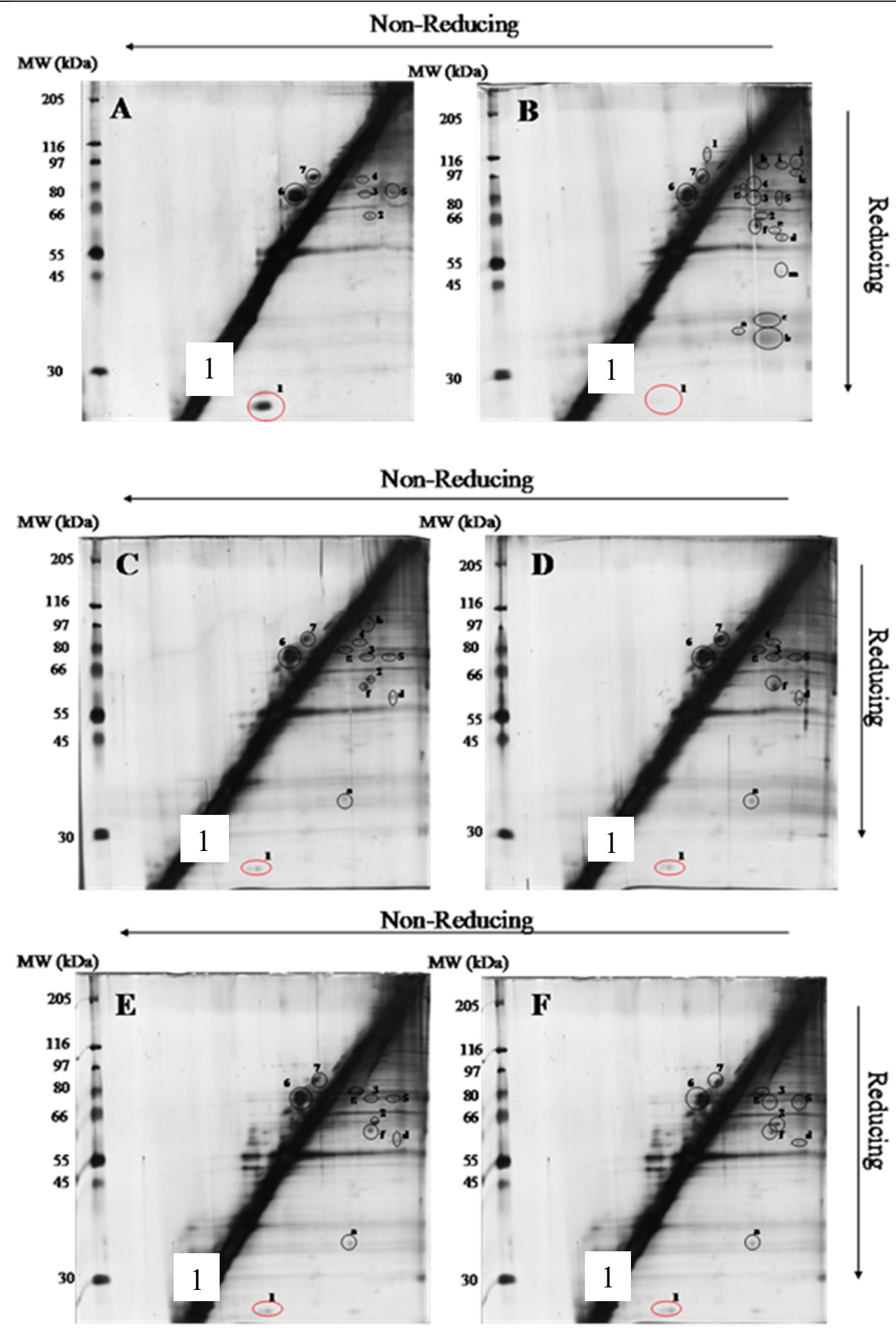

Figure 6. 


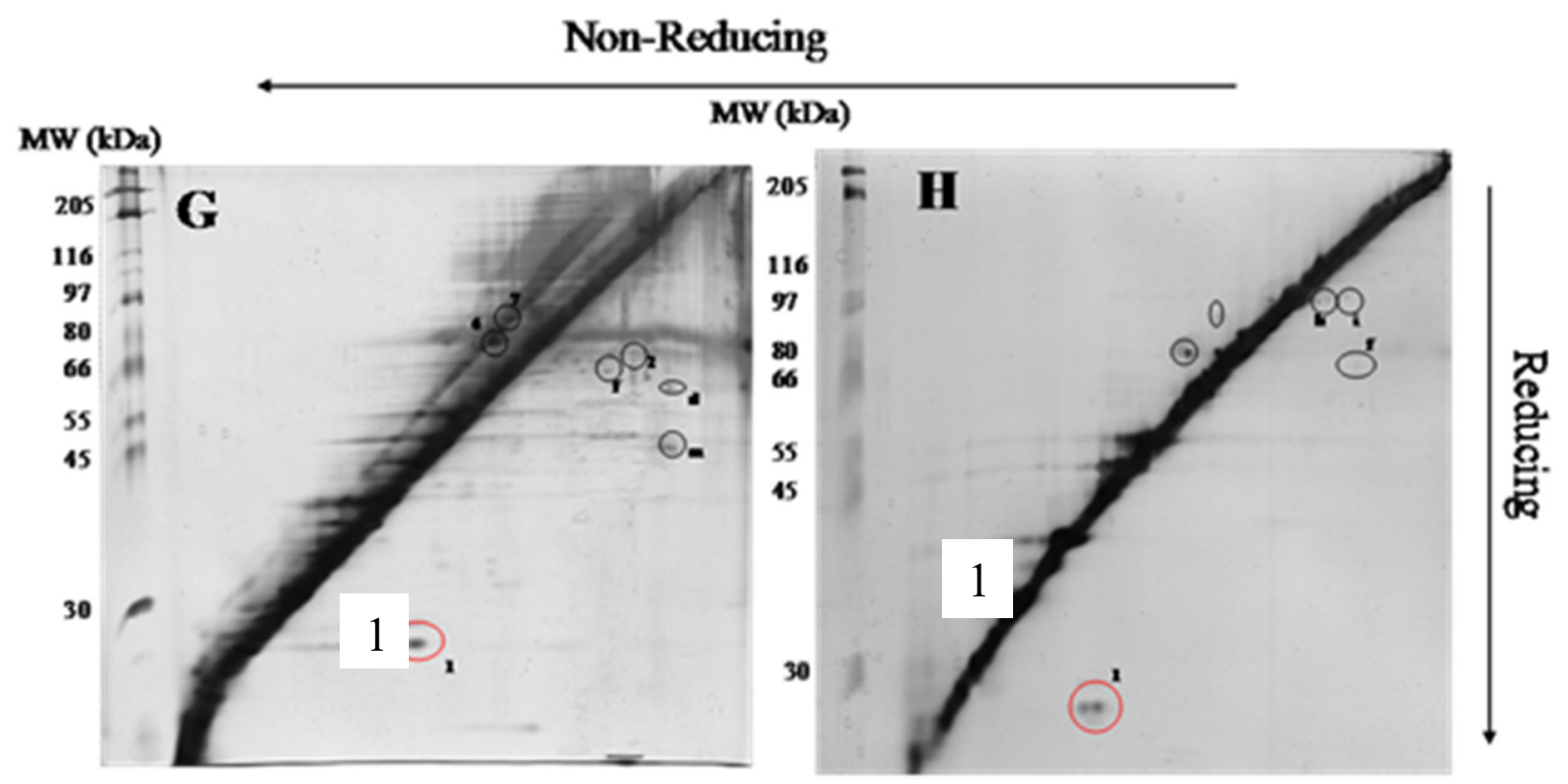

Figure 6. Chemoprotective effects of $5 \mu \mathrm{M}$ BE (C), Cro (D), Res (E), Sal (F), MIX 1 (G) or MIX 2 (H) on $400 \mu \mathrm{M}$ SMXNHOH-induced oxidation of Jurkat E6.1 cells (B) analyzed by R2D SDS PAGE and silver staining. The protein spots seen in the vehicle control (A) are identified by numbers (1-7) whereas those that occur only after treatment with SMX-NHOH are identified by letters (a-1; Table 5). Mitochondrial supernatant ( $85 \mu \mathrm{g}$ protein) was loaded on all gels which were run in triplicate for each experiment, and the experiment was repeated three times with different cell cultures (i.e. 9 gels for each treatment).

The effectiveness of the inhibition of oxidation of the disulfide proteome by the various TCM treatments was evaluated using 2 criteria; first by examining the presence and relative size of prx 2 (spot 1) in the gels; and second, by determining changes in SMX-NHOH-specific spots (Table 5).

Based on an analysis of prx 2 hyperoxidation (disappearance), each of the single TCM compounds and defined mixture treatments partially attenuated oxidation of the disulfide proteome. The prx 2 spot which is prominent in solvent controls (Figure 6A) is absent from mitochondrial supernatant of Jurkat E6.1 cells treated with $400 \mu \mathrm{M}$ SMX-NHOH for $2 \mathrm{~h}$ (Figure 6B). A faint prx 2 spot, indicating partial chemoprotection from SMX-NHOH is visible in gels from cells pretreated with $5 \mu \mathrm{M} \mathrm{BE}$ (Figure 6C), Cro (Figure 6D), Res (Figure 6E), Sal (Figure 6F), MIX 1 (Figure 6G) or MIX 2 (Figure 6H) before SMX$\mathrm{NHOH}$. It is clear from Figure 6 that more prx 2 is present in cells pretreated with MIX 1 (Figure 6G) or
MIX 2 (Figure $6 \mathrm{H}$ ) than with any of the single treatments.

Each of the numbers in Table 5 represents the number of experiments in which a specific spot was found. Thus, $1 \mu \mathrm{M}$ BE, Res and Sal did not attenuate the disappearance (hyperoxidation) of prx 2 whereas each of the other treatments did. One way to assess the chemoprotection of the various TCM regimens against SMX-NHOH-dependent oxidation of the disulfide proteome is to compare the number of spots that disappear (i.e. protein-protein disulfides that are no longer formed). At $5 \mu \mathrm{M}$. this number is 5 for BE; 6 for Cro; 6 for Res; 7 for Sal; 7 for MIX 1; and 7 for MIX 2, demonstrating that all regimens were able to partially protect against P-SS-P/P' formation. When both endpoints are considered, it is clear that the chemoprotection offered by MIX 1 and MIX2 against oxidation of redox-regulated proteins by SMX-NHOH is better than for any of the single TCM constituents. 
Table 5. Protein spots on R2D SDS-PAGE gels formed by reduction of protein-protein disulfides (a-1) or by preventing oxidation of peroxiredoxin 2 (spot 1) to prx 2 sulfinic acid. The numbers represent the number of experiments of a total of 3 where a specific spot was present on the gel.

\begin{tabular}{|c|c|c|c|c|c|c|c|c|c|c|c|c|c|}
\hline $\begin{array}{c}\text { Monomeric mol wt (kDa) } \\
\text { Protein spots }^{2}\end{array}$ & $\begin{array}{c}25 \\
1\end{array}$ & $\begin{array}{c}30 \\
\text { a }\end{array}$ & $\begin{array}{c}35 \\
\text { b }\end{array}$ & $\begin{array}{c}37 \\
\text { c }\end{array}$ & $\begin{array}{c}39 \\
\text { d }\end{array}$ & $\begin{array}{c}60 \\
\mathrm{e}\end{array}$ & $\begin{array}{c}65 \\
\text { f }\end{array}$ & $\begin{array}{c}90 \\
\mathrm{~g}\end{array}$ & $\begin{array}{c}112 \\
\mathrm{~h}\end{array}$ & $\begin{array}{c}114 \\
\text { i }\end{array}$ & $\begin{array}{c}115 \\
j\end{array}$ & $\begin{array}{c}116 \\
k\end{array}$ & $\begin{array}{c}130 \\
1\end{array}$ \\
\hline Control (0.2\% DMSO) & 3 & $\mathbf{0}$ & $\mathbf{0}$ & $\mathbf{0}$ & $\mathbf{0}$ & $\mathbf{0}$ & $\mathbf{0}$ & $\mathbf{0}$ & $\mathbf{0}$ & $\mathbf{0}$ & $\mathbf{0}$ & $\mathbf{0}$ & $\mathbf{0}$ \\
\hline SMX-NHOH (400 $\mu \mathrm{M})[\mathrm{HA}]$ & $\mathbf{0}$ & 3 & 2 & 2 & 3 & 3 & 2 & 3 & 2 & 3 & 3 & 2 & 2 \\
\hline $1 \mu \mathrm{M} \mathrm{BE}+\mathrm{HA}$ & $\mathbf{0}$ & 3 & $\mathbf{0}$ & $\mathbf{0}$ & 3 & 3 & 1 & 3 & $\mathbf{0}$ & 2 & 2 & $\mathbf{0}$ & 1 \\
\hline $5 \mu \mathrm{M} \mathrm{BE}+\mathrm{HA}$ & 3 & 2 & $\mathbf{0}$ & $\mathbf{0}$ & 1 & $\mathbf{0}$ & 1 & 3 & $\mathbf{0}$ & 2 & 2 & $\mathbf{0}$ & 1 \\
\hline $1 \mu \mathrm{M}$ Cro + HA & 3 & 1 & $\mathbf{0}$ & $\mathbf{0}$ & $\mathbf{0}$ & 3 & 3 & 3 & 3 & $\mathbf{0}$ & 1 & 2 & $\mathbf{0}$ \\
\hline $5 \mu \mathrm{M} \mathrm{Cro}+\mathrm{HA}$ & 3 & 2 & $\mathbf{0}$ & $\mathbf{0}$ & 2 & 3 & 2 & 1 & $\mathbf{0}$ & $\mathbf{0}$ & $\mathbf{0}$ & $\mathbf{0}$ & 2 \\
\hline $1 \mu \mathrm{M} \operatorname{Res}+\mathrm{HA}$ & $\mathbf{0}$ & 3 & $\mathbf{0}$ & 2 & 2 & 3 & 2 & 1 & 2 & $\mathbf{0}$ & $\mathbf{0}$ & $\mathbf{0}$ & 2 \\
\hline $5 \mu \mathrm{M} \operatorname{Res}+\mathrm{HA}$ & 3 & 3 & $\mathbf{0}$ & $\mathbf{0}$ & 3 & 3 & 2 & 2 & $\mathbf{0}$ & $\mathbf{0}$ & $\mathbf{0}$ & $\mathbf{0}$ & 1 \\
\hline $1 \boldsymbol{\mu M}$ Sal + HA & $\mathbf{0}$ & 3 & $\mathbf{0}$ & 1 & $\mathbf{0}$ & 2 & 3 & 3 & 2 & 3 & $\mathbf{0}$ & $\mathbf{0}$ & $\mathbf{0}$ \\
\hline $5 \mu \mathrm{M}$ Sal + HA & 3 & 3 & $\mathbf{0}$ & $\mathbf{0}$ & $\mathbf{0}$ & 3 & 3 & 2 & $\mathbf{0}$ & $\mathbf{0}$ & $\mathbf{0}$ & 1 & $\mathbf{0}$ \\
\hline $1 \mu$ M MIX 1 + HA & 3 & 1 & $\mathbf{0}$ & $\mathbf{0}$ & $\mathbf{0}$ & $\mathbf{0}$ & 3 & 3 & 3 & 2 & 3 & 2 & $\mathbf{0}$ \\
\hline $5 \mu$ M MIX 1 + HA & 3 & $\mathbf{0}$ & $\mathbf{0}$ & $\mathbf{0}$ & $\mathbf{0}$ & $\mathbf{0}$ & 3 & 3 & 3 & $\mathbf{0}$ & 2 & 0 & 3 \\
\hline $1 \mu \mathrm{M}$ MIX $2+$ HA & 3 & $\mathbf{0}$ & $\mathbf{0}$ & $\mathbf{0}$ & 1 & 1 & 3 & 3 & 3 & 2 & 2 & 1 & $\mathbf{0}$ \\
\hline $5 \mu \mathrm{M}$ MIX $2+$ HA & 3 & $\mathbf{0}$ & $\mathbf{0}$ & $\mathbf{0}$ & 3 & 3 & 3 & 3 & 0 & $\mathbf{0}$ & 3 & $\mathbf{0}$ & $\mathbf{0}$ \\
\hline
\end{tabular}

${ }^{1}$ Mol wt in kDa estimated using mol wt markers on R2D SDS-PAGE slab gels

${ }^{2}$ Spot 1 is prx 2; spots a-l appear only upon treatment of Jurkat E6.1 cells with $400 \mu \mathrm{M}$ SMX-NHOH

However, on the positive side, it is equally obvious that all treatment regimens tested are chemoprotective against SMX-NHOH-dependent oxidation of proteins at ionized cysteine thiols, a probable contributing mechanism to the ADRs to SMX via immunogenic hapten formation.

\section{DISCUSSION}

It is now well established that ADRs to the sulfonamide, SMX are caused by its electrophilic metabolite, SMX-NHOH (formed by cytochrome P450 monooxygenases in liver and extrahepatic tissues; and MYO in blood cells) and its autooxidation product, SMX-NO. Both SMX-NHOH and SMX-NO show selectivity when they bind covalently to proteins to form haptens (Figure $1 ; 2,6,12,15,17)$, indicating probable covalent reaction with protein reactive cysteine thiols (54). AIDS patients have depleted intracellular GSH (i.e. increased GSSG/GSH ratio), contributing to the $50 \%$ incidence of ADRs to SMX therapy in this group vs $3-4 \%$ in the normal population (2). This extremely high ADR incidence in these oxidatively stressed patients reflects the fact that SMX-NHOH and SMX$\mathrm{NO}$ are both electrophilic and oxidative stressors, dual contributors to SMX hypersensitivity (Figure 1; $6,10,11,12,14)$. In addition, GSH is required for detoxication both of the electrophilic SMX metabolites, (by formation of GSH conjugates; 6,10) and the ROS/RNS they indirectly generate (by formation of S-glutathionylated proteins;
47,48,50,56,57). Depleted intracellular GSH facilitates increased covalent binding of SMX$\mathrm{NHOH}$ and SMX-NO to proteins (increased hapten formation) (Figure 1; 14,15) and increased oxidation of redox-regulated proteins to irreversible products such as $\mathrm{P}-\mathrm{SO}_{2} \mathrm{H}, \mathrm{P}-\mathrm{SO}_{3} \mathrm{H}$ and polymeric protein disulfides $(40,42,46,47)$, known contributors to pathology.

We hypothesize that complementary therapy with either single or defined, simple mixtures of TCM constituents with potent antioxidant activity will attenuate SMX-mediated ADRs by: 1) decreasing formation of ROS/RNS and/or increasing detoxication of these radicals, enhancing intracellular GSH (decrease GSSG/GSH ratio); and 2) increasing metabolic detoxication of SMX$\mathrm{NHOH}$ and SMX-NO by GSH-dependent pathways. In this study we were able to show that mixtures are less cytotoxic than single TCM constituents at equimolar concentrations (Table 1).

Exposure of Jurkat E6.1 cells in culture to SMX$\mathrm{NHOH}(400 \mu \mathrm{M}$ for $2 \mathrm{~h})$ initiated several responses associated with toxicity. This oxidative metabolite of SMX caused significant $(\mathrm{P} \leq 0.05)$ release of $28-32 \%$ of total intracellular $\mathrm{LDH}$, a sensitive assay for cytotoxicity (Figure 3; Table 2); a more than 2-fold increase in lipid peroxide content, an index of oxidative/nitrosative stress (Figure 4, Table 3); a significant increase $(\mathrm{P}<0.05)$ in protein carbonylation, a biomarker for irreversible protein oxidation by ROS/RNS, by $145 \%$ (250土 $28 \%$, mean $\pm \mathrm{SEM}, \mathrm{N}=3$ vs $100 \%$, in solvent controls) (Figure 5; 
Table 4); and significant oxidation of redox proteins regulated by reactive (ionized) cysteine thiol residues (i.e. oxidative changes to the disulfide proteome by ROS/RNS) as shown by 1 ) the hyperoxidation of prx 2 (Figure 6, Table 5); and 2) the appearance of 12 novel SMX-NHOH-specific monomeric protein thiols, labelled "a" to "l", following DTT reduction of protein-protein disulfides (Figure 6B; Table 5). There are probably more redox-regulated proteins in Jurkat E6.1 cells oxidized by SMX-NHOH not detected in our R2D SDS-PAGE experiments. This is because a limitation of this technique is that it only works well for cellular proteins present at relatively high concentrations.

A related mass spectroscopy (MS)-based proteomic study of Jurkat cells treated with $200 \mu \mathrm{M}$ $\mathrm{H}_{2} \mathrm{O}_{2}$ for 10 min identified 28 spots that were reversibly oxidized (i.e. P-SS-G, P-SS-P or P-SS-P') and 24 spots that decreased in intensity/size following oxidation, including prx 2 (56). A second MS-based study identified 38 different redoxregulated proteins in $\mathrm{T}$ cell blasts that form $\mathrm{S}$ glutathionylated derivatives (P-SS-G) upon oxidation with $1 \mathrm{mM} \mathrm{H}^{2} \mathrm{O}^{2}$ or $1 \mathrm{mM}$ Diamide for 5 $\min (57)$.

This collection of toxicological endpoints (cytotoxicity, lipid peroxidation, protein carbonylation and oxidation of the disulfide proteome) for $\mathrm{SMH}-\mathrm{NHOH}$ allowed us to evaluate the chemoprotection provided against this SMX metabolite by low concentrations of BE, Cro, Res or Sal and 2 defined mixtures; MIX 1 which contains equimolar amounts of all 4 phytochemicals and MIX 2 , an equimolar mixture of $\mathrm{BE}, \mathrm{Cro}$ and Res. One reason for comparing these mixtures to each other was to evaluate the contribution of poorly investigated Sal to chemoprotection in the presence of other well characterized antioxidants.

All chemicals evaluated effectively protect against SMX-NHOH cytotoxicity at $1 \mu \mathrm{M}(31-65 \%$ attenuation of LDH leakage) or $5 \mu \mathrm{M}(57-93 \%$ attenuation; Table 1). The only significant difference noted is that $\mathrm{BE}$ is less effective than MIX 1 at both concentrations $(\mathrm{P} \leq 0.05)$. The mean attenuation with MIX 1 was $55 \%$ at $1 \mu \mathrm{M}$ and $93 \%$ at $5 \mu \mathrm{M}$; that for MIX 2 was $53 \%$ and $93 \%$, respectively. These were the only treatments that exceeded $90 \%$ efficacy at 5 $\mu \mathrm{M}$. In terms of cytotoxicity, none of the treatments cause any increase in LDH release, compared to the solvent control at the concentrations tested for chemoprotection (Table 1; Figure 3). Similarly, all
TCM treatment regimens offered chemoprotection against SMX-NHOH-induced lipid peroxidation. Both mixtures inhibited about $95 \%$ of lipid peroxidation at the higher concentration $(20 \mu \mathrm{M})$ studied (Table 2). In addition, all TCM treatments inhibit SMX-NHOH-mediated protein carbonylation at $5 \mu \mathrm{M}$ by more than $45 \%$ but MIX 1 attenuated protein carbonylation by $20 \%$ more than any of the single treatments (although this difference is not significant, Table 3 ).

With regard to partially preventing the SMX$\mathrm{NHOH}$-dependent hyperoxidation of prx 2 to its sulfinic acid form, all treatments showed partial chemoprotection at $5 \mu \mathrm{M}$ but only Cro, MIX 1 and MIX 2 did so at $1 \mu \mathrm{M}$ in 3 independent experiments (Figures 6C to 6H; Table 5). However, MIX 1 and MIX 2 are slightly superior chemoprotectants (Figures $6 \mathrm{G}$ and $6 \mathrm{H}$; larger prx 2 spot) than equimolar concentrations of $\mathrm{BE}$, Cro, Res or Sal (Figures 6C to 6F).

Another significant change that occurred in the disulfide proteome as the result of exposing Jurkat E6.1 cells to SMX-NHOH was the appearance of 12 specific monomeric protein thiol spots on R2D SDSPAGE gels never present in solvent controls (Figure $6 \mathrm{~B}$ vs $6 \mathrm{~A}$; Table 4$)$. The mol wt of the spots present in all 3 experiments was determined from the R2D SDS-PAGE gels (a, $30 \mathrm{kDa}$; d, $39 \mathrm{kDa}$; e, $60 \mathrm{kDa}$; $\mathrm{g}, 90 \mathrm{kDa} ; \mathrm{i}, 114 \mathrm{kDa}$ and j, $115 \mathrm{kDa}$ ) and the other 6 (b, $35 \mathrm{kDa}$; c, $37 \mathrm{kDa}$; f, $65 \mathrm{kDa}$; h,112 kDa; k, 116 $\mathrm{kDa}$; and 1, $130 \mathrm{kDa}$ were present on gels from 2 of the 3 experiments. Although these protein spots were not identified in our study redox-regulated proteins containing reactive cysteine thiol of identical mol wt were previously identified in Jurkat cells (56) and in $\mathrm{T}$ cell blasts (57) subjected to oxidative stress. Thus, the protein at $114 \mathrm{kDa}$ (i) is possibly ubiquitin thiolesterase 16; at $60 \mathrm{kDa}(\mathrm{e})$, HSP 60 ; at $39 \mathrm{kDa}$ (d), GAPDH or aldolase; and at $37 \mathrm{kDa}(\mathrm{b}), \alpha-$ enolase.

As a result of this proof-of-principle study we believe that carefully designed mixtures of potent phytochemicals with different mechanisms of chemoprotective action have potential for complementary therapy against ADRs where oxidative and nitrosative stress play a causative role. This potential can be increased by including ingredients which are rapidly absorbed, initiate their activity quickly and are rapidly eliminated as conjugates formed directly by rapid phase 2 metabolism, in addition to compounds like Sal which have prolonged bioactivity in vivo due to the 
conversion of 5 phenolic methyl ethers to antioxidant phenols by slower phase 1 cytochrome P450dependent oxidation.

\section{ACKNOWLEDGEMENTS}

This research was funded by CIHR grant MOP-9972 to JRB; by a Hospital for Sick Children Foundation grant to MJR, JRB and A. Lau; and by an Ontario Ministry of Research and Innovation: International Strategic Opportunities Program grant to MJR, JRB and DFC.

\section{REFERENCES}

1. Park BK, Pirmohamed M, Kitteringham NR. Idiosyncratic drug reactions: a mechanistic evaluation of risk factors. Br J Clin Pharmacol, 1992; 34:377395.

2. Castrejon JL, Lavergne, SN, El-Sheikh A, Farrell J, . Maggs JL, Sabbani S, O'Neill PM, Park BK, Naisbitt DJ. Metabolic and chemical origins of cross-reactive immunological reactions to arylamine benzenesulfonamides: T-cell responses to hydroxylamine and nitroso derivatives. Chem Res Toxicol, 2010; 23: 184-192.

3. Rawlins M.; Thompson J, Pathogenesis of adverse drug reactions, in Davies D: Oxford D (eds), Textbook of Adverse Drug Reactions, ed. Davies D.; Oxford D, Oxford University Press, Oxford, UK, UK, p 10, 1977.

4. Elzagallaai AA, Rieder MJ. In vitro testing for diagnosis of idiosyncratic adverse drug reactions: Implications for pathophysiology. $\mathrm{Br} \mathrm{J}$ Clin Pharmacol, 2014; doi; 10.1111/bcp.12505.

5. Johansson SG, Bieber T, Dahl R, Friedmann PS, Lanier Q, Lockey RF, Motala C, Ortega Martell JA, Platts-Mills TA, Ring J, Tien JF, Van Cauwenberge $\mathrm{P}$, Williams HC. Revised nomenclature for allergy for global use: report of the Nomenclature Review Committee of the World Allergy Organization. J Allergy Clin Immunol, 2004; 113:832-836.

6. Naisbitt DJ, Hough SJ, Gill HJ, Pirmohamed M, Kitteringham NR, Park BK. Cellular disposition of sulphamethoxazole and its metabolites: implications for hypersensitivity. Br J Pharmacol, 1999; 126:13931407.

7. Vree TB, van der Ven AJ, Verwey-van Wissen CP, van Ewijk-Beneken Kolmer EW, Swolfs AE, van Galen PM, Amatdjais-Groenen H. Isolation, identification and determination of sulfamethoxazole and its known metabolites in human plasma and urine by high-performance liquid chromatography. J Chromatogr B Biomed Appl, 1994; 658:327-340.

8. Cribb AE, Spielberg SP, Griffin GP. N4hydroxylation of sulfamethoxazole by cytochrome
P450 of the cytochrome P4502C subfamily and reduction of sulfamethoxazole hydroxylamine in human and rat hepatic microsomes. Drug Metab Dispos, 1995; 23:406-414.

9. Cribb AE, Miller M, Tesoro A, Spielberg SP. Peroxidase-dependent oxidation of sulfonamides by monocytes and neutrophils from humans and dogs. Mol Pharmacol, 1990; 38:744-751.

10. Rieder MJ, Uetrecht J, Shear NH, Spielberg SP. Synthesis and in vitro toxicity of hydroxylamine metabolites of sulfonamides. J Pharmacol Exp Ther, 1988; 244:724-728.

11. Rieder MJ, Krause R, Bird IA. Time-course of toxicity of reactive sulfonamide metabolites. Toxicology, 1995; 95:141-146.

12. Manchanda T, Hess D, Dale L, Ferguson SG, Rieder MJ. Haptenation of sulfonamide reactive metabolites to cellular proteins. Mol Pharmacol, 2002; 62:10111126.

13. Sanderson JP, Naisbitt DJ, Farrell J, Ashby CA, Tucker MJ, Rieder MJ, Pirmohamed M, Clarke SE, Park BK. sulfamethoxazole and its metabolite nitroso sulfamethoxazole stimulate dendritic cell costimulatory signaling. J Immunol, 2007; 178:55335542.

14. Vyas PM, Roychowdhury S, Woster PM, Svebsson $\mathrm{CK}$. Reactive oxygen species generation and its role in the differential cytotoxicity of the arylhydroxylamine metabolites of sulfamethoxazole and dapsone in normal human epidermal keratinocytes. Biochem Pharmacol, 2005; 70: 275286.

15. Vyas PM, Roychowdhury S, Koukouritaki SB, Hines RN, Krueger SK, Williams DE, Nauseef WM, Svensson SK. Enzyme-mediated protein haptenation of dapsone and sulfamethoxazole in human keratinocytes: II. Expression and role of flavincontaining monooxygenases and peroxidases. J Pharmacol Exp Ther, 2006; 19:497-505.

16. Yoshikawa, Hosomi H, Fukami T, Nakajima M, Yokoi T. Establishment of knockdown of superoxide dismutase 2 and expression of CYP3A4 cell system to evaluate drug-induced cytotoxicity. Toxicol In Vitro, 2009; 23: 1179-1187.

17. Bhaiya P, Roychowdhury S, Vyas PM, Doll MA, Hein DW, Svensson SK. Bioactivation, protein haptenation, and toxicity of sulfamethoxazole and dapsone in normal human dermal fibroblasts. Toxicol Appl Pharmacol, 2006; 215:158-167.

18. Kohen R, Nyska A. Oxidation of biological systems: oxidative stress phenomena, antioxidants, redox reactions, and methods for their quantification. Toxicol Pathol, 2002; 30:620-650.

19. Halliwell B. Free radicals, antioxidants, and human disease: curiosity, cause, or consequence? Lancet, 1994; 344:721-724. 
20. Williams DP, Park BK. Idiosyncratic toxicity: the role of toxicophores and bioactivation. Drug Discov Today, 2003; 8:1044-1050.

21. Wang L, Ling Y, Chen Y, Li CL, Feng F, You QD, Lu N, Guo QL. Flavonoid baicalein suppresses adhesion, migration and invasion of MDA-MB-231 human breast cancer cells. Cancer Lett, 2010; 297: 42-48.

22. Lai, MY, Hsiu SL, Chen CC, Hou YC, Chao PD. Urinary pharmacokinetics of baicalein, wogonin and their glycosides after oral administration of Scutellariae Radix in humans. Biol Pharm Bull, 2003; 26: 79-83.

23. Kanakis CD, Tarantilis PA, Tajmir-Riahi HA, Polissiou MG. Crocetin, dimethylcrocetin, and safranal bind human serum albumin: stability and antioxidative properties. J Agric Food Chem, 2007; 55: 970-977.

24. Ordoudi SA, Befani CD, Nenadis N, Koliakos GG, Tsimidou MZ. Further examination of antiradical properties of Crocus sativus stigmas extract rich in crocins. J Agric Food Chem, 2009; 57:3080-3086.

25. Das S, Das DK. Resveratrol: a therapeutic promise for cardiovascular diseases. Recent Pat Cardiovasc Drug Discov, 2007; 2:133-138.

26. Bereswill S, Munoz M, Fischer A, Plickert R, Haag LM, Otto B, Kühl AA, Loddenkemper C, Göbel UB, Heimesaa MM. Anti-inflammatory effects of resveratrol, curcumin and simvastatin in acute small intestinal inflammation. PLoS One, 2010; 5(12):e15099. doi: 10.1371.

27. Liu C, Shi Z, Fan L, Zhang C, Wang K, Wang B. Resveratrol improves neuron protection and functional recovery in rat model of spinal cord injury. Brain Res, 2011; 1374:100-9. doi: 10.1016.

28. Kapetanovic IM, Muzzio M, Huang Z, Thompson TN, McCormick DL. Pharmacokinetics, oral bioavailability, and metabolic profile of resveratrol and its dimethylether analog, pterostilbene, in rats. Cancer Chemother Pharmacol, 2011; 68:593-601.

29. Lin TJ, Liu GT, Pan Y, Liu Y, Xu GZ. Protection by schisanhenol against adriamycin toxicity in rat heart mitochondria. Biochem Pharmacol, 1991; 42:18051810.

30. Lin Y, Liu G, Pan Y. Protective effect of schisanhenol against oxygen radical induced mitochondrial toxicity on rat heart and liver. Biomed Environ Sci, 1992; 5:57-64.

31. Yu YT, Liu GT, Sun YM, Zhang HY. Antioxidative effect of schisanhenol on human low density lipoprotein and its quantum chemical calculation, Acta Pharmacol Sin, 2004; 25:1038-1044.

32. Chen M, Kilgore N, Lee HK, Chen DF. Rubrisandrins $\mathrm{A}$ and $\mathrm{B}$, lignans and related anti-HIV compounds from Schisandra rubriflora. J Nat Prod, 2006; 69: 1697-1701.
33. Wei H, Sun L, Tai Z, Gao S, Xu W, Chen W. A simple and sensitive HPLC method for the simultaneous determination of eight bioactive components and fingerprint analysis of Schisandra sphenanthera. Anal Chim Acta, 2010; 662:97-104.

34. Naisbitt DJ, Pirmohamed M, Park BK. Immunological principles of T-cell-mediated adverse drug reactions in skin. Expert Opin Drug Saf, 2007; 6:109-124.

35. Lu Y, Chen DF. Analysis of Schisandra chinensis and Schisandra sphenanthera. J Chromatogr A, 2009; 1216: 1980-1990.

36. Weiss A, Wiskocil RL, Stobo JD. The role of T3 surface molecules in the activation of human T cells: a two-stimulus requirement for IL 2 production reflects events occurring at a pre-translational level. J Immunol, 1984; 133:123-128.

37. Lowry OH, Rosebrough NJ, Farr AL, Randall RJ. Protein measurement with the Folin phenol reagent. J Biol Chem, 1951; 193:265-275.

38. Korzeniewski C, Callewaert DM. An enzyme-release assay for natural cytotoxicity. J Immunol Methods, $1983 ; 64: 313-320$.

39. Mihaljevic B, Katusin-Razem B, Razem D. The reevaluation of the ferric thiocyanate assay for lipid hydroperoxides with special considerations of the mechanistic aspects of the response. Free Radic Biol Med, 1996; 21:53-63.

40. Dalle-Donne I, Rossi R, Giustarini D, Milzani A, Colombo R. Protein carbonyl groups as biomarkers of oxidative stress. Clin Chim Acta, 2003; 329: 23-38.

41. Dalle-Donne I, Scaloni A, Giustarini D, Cavarra E, Tell G, Lungarella G, Colombo R, Rossi R, Milzani A. Proteins as biomarkers of oxidative/nitrosative stress in diseases: the contribution of redox proteomics. Mass Spectrom Rev, 24:55-99, 2005.

42. Dirmeier R, O'Brien K, Engle M, Dodd A, Spears E, Poyton RO. Measurement of oxidative stress in cells exposed to hypoxia and other changes in oxygen concentration. Methods Enzymol, 2004; 381: 589603.

43. Cumming RC, Andon NL, Haynes PA, Park M, Fischer WH, Schubert D. Protein disulfide bond formation in the cytoplasm during oxidative stress. J. Biol. Chem, 2004; 279:21749-21758.

44. Gotham SM, Fryer PJ, Paterson WR. The measurement of insoluble proteins using a modified Bradford assay. Anal Biochem, 1988; 1732:353-358.

45. Shevchenko A, Wilm M, Vorm O, Mann M. Mass spectrometric sequencing of proteins silver-stained polyacrylamide gels. Anal Chem, 1996; 68:850-858.

46. McIntyre TM, Hazen SL. Lipid oxidation and cardiovascular disease: introduction to a review series. Circ Res, 2010; 107:1167-1169.

47. Mieyal JJ, Gallogly MM, Qanungo S, Sabens EA, Shelton, MD. Molecular mechanisms and clinical implications of reversible protein S-glutathionyl- 
ation. Antioxid Redox Signal, 2008; 10: 1941-1948, 2008.

48. Lindahl M, Mata-Cabana A, Kieselbach T. The disulfide proteome and other reactive cysteine proteomes: analysis and functional significance. Antioxid Redox Signal, 2011; 14:2581-2642.

49. Martínez-Ruiz A, Lamas S. Signalling by NOinduced protein S-nitrosylation and Sglutathionylation: convergences and divergences. Cardiovasc Res, 2007; 75:220-228.

50. Bend JR, Xia XY, Chen DF, Awaysheh A, Lo A, Rieder MJ, Rylett RJ. Attenuation of oxidative stress in HEK 293 cells by the TCM constituents Schisanhenol, Baicalein, Resveratrol or Crocetin and Two Defined Mixtures, J Pharmacy Pharm Sci, Special Issue, submitted for review.

51. Rhee SG, Cha HZ, Kim K. Peroxiredoxins: A historical overview and speculative preview of novel mechanisms and emerging concepts in cell signaling. Free Radic Biol Med, 2005; 38:1543-1552.

52. Wood ZA, Schroder E, Robin Harris J, Poole LB. Structure, mechanism and regulation of peroxiredoxins. Trends Biochem Sci, 2003; 28:32-40.

53. Woo HA, Kang SW, Kim HK, Yang KS, Chae HZ, Rhee SG. Reversible oxidation of the active site cysteine of peroxiredoxins to cysteine sulfinic acid. Immunoblot detection with antibodies specific for the hyperoxidized cysteine-containing sequence. J Biol Chem, 2003; 278:47361-47364.

54. Cho CS, Lee S, Lee GT, Woo HA, Choi EJ, Rhee SG. Irreversible inactivation of glutathione peroxidase 1 and reversible inactivation of peroxiredoxin II by $\mathrm{H} 2 \mathrm{O} 2$ in red blood cells. Antioxid Redox Signal, 2010; 12:1235-1246.

55. Shin NY, Liu Q, Stamer SL, Liebler DC. Protein targets of reactive electrophiles in human liver microsomes. Chem Res Toxicol, 2007; 20:859-867.

56. Baty JW, Hampton MB, Winterbourn CC. Proteomic detection of hydrogen peroxide-sensitive thiol proteins in Jurkat cells. Biochem J, 2005; 389(Pt 3):785-795.

57. Fratelli M, Demol H, Puype M, Casagrande S, Eberini I, Salmona, M. Bonetto V, Mengozzi M, Duffieux F, Miclet E, Bachi A, Vandekerckhove J, Gianazza E, Ghezzi P. Identification by redox proteomics of glutathionylated proteins in oxidatively stressed human T lymphocytes. Proc Natl Acad Sci USA, 2002; 99:3505-3510. 